\title{
Production of Biodiesel from Castor Oil: A Review
}

\author{
Carlos S. Osorio-González ${ }^{1,+}+\left(\mathbb{C}\right.$, Natali Gómez-Falcon ${ }^{2,+}{ }^{\text {, Fabiola Sandoval-Salas }}{ }^{3}{ }^{(0)}$, \\ Rahul Saini ${ }^{1}$, Satinder K. Brar ${ }^{1, *}$ and Antonio Avalos Ramírez ${ }^{4, *}$ \\ 1 Department of Civil Engineering, Lassonde School of Engineering, York University, \\ North York, TO M3J 1P3, Canada; carloso@yorku.ca (C.S.O.-G); rahul53@yorku.ca (R.S.) \\ 2 Department of Biotechnology, Scientific Research Center of Yucatan, Mérida 97205, Mexico; \\ natali.gomez@cicy.mx \\ 3 Subdirection of Research and Postgraduate Studies, Tecnológico Nacional de México/ITS Perote, \\ Perote 91270, Mexico; direccion.academica@itsperote.edu.mx \\ 4 Centre national en électrochimie et en technologies environnementales, Shawinigan, QC G9N 6V8, Canada \\ * Correspondence: Satinder.brar@lassonde.yorku.ca (S.K.B.); aaramirez@cnete.qc.mx (A.A.R.) \\ + First authors contributed equally.
}

Received: 3 March 2020; Accepted: 11 May 2020; Published: 14 May 2020

check for updates

\begin{abstract}
An attractive alternative to the use of fossil fuels is biodiesel, which can be obtained from a variety of feedstock through different transesterification systems such as ultrasound, microwave, biological, chemical, among others. The efficient and cost-effective biodiesel production depends on several parameters such as free fatty acid content in the feedstock, transesterification reaction efficiency, alcohol:oil ratio, catalysts type, and several parameters during the production process. However, biodiesel production from vegetable oils is under development, causing the final price of biodiesel to be higher than diesel derived from petroleum. An alternative to decrease the production costs will be the use of economical feedstocks and simple production processes. Castor oil is an excellent raw material in terms of price and quality, but especially this non-edible vegetable oil does not have any issues or compromise food security. Recently, the use of castor oil has attracted attention for producing and optimizing biodiesel production, due to high content of ricinoleic fatty acid and the possibility to esterify with only methanol, which assures low production costs. Additionally, biodiesel from castor oil has different advantages over conventional diesel. Some of them are biodegradable, non-toxic, renewable, they can be used alone, low greenhouse gas emission, among others. This review discusses and analyzes different transesterification processes, technologies, as well as different technical aspects during biodiesel production using castor oil as a feedstock.
\end{abstract}

Keywords: biodiesel; castor oil; transesterification; purification; R. communis

\section{Introduction}

Biodiesel definition according to the American Society for Testing and Materials (ASTM) is a fuel composed mainly of mono-alkyl esters derived from renewable vegetable oils or animal fats meeting the ASTM D6751 requirements. Biodiesel is an environmentally friendly biofuel as the net greenhouse gas emission is lower than that of fossil fuels [1]. Biodiesel is produced from renewable sources, is biodegradable, non-toxic, free of aromatic compounds, and for instance biodiesel from castor oil has a lower cetane number (43.7) than that of conventional diesel (51) [2]. One of the main advantages of biodiesel is its high content of oxygen $(>10 \%)$ that promotes and improves combustion processes in diesel engines. In addition, it does not contain sulphur, therefore no harmful sulphur oxides are generated during its combustion and released into the environment [3,4]. Several raw materials are used to produce biodiesel, such as glycerides or vegetable oils as they have a high calorific value. Additionally, the use of feedstocks as vegetable oils can contribute to decreasing greenhouses gases 
such as carbon dioxide, because these oils are obtained from crops which have previously captured this gas during their photosynthetic process [5-7].

Ricinus communis (castor bean) is a high potential feedstock, which could supply up to $60 \%$ of the non-edible oil needed to produce biodiesel. Castor bean plants present strong adaptation to different weather, being able to grow in marginal soils. The main fatty acid in castor oil is ricinoleic acid $\left(\mathrm{C}_{18} \mathrm{H}_{34} \mathrm{O}_{3}\right)$, with approximately $80-90 \%$ of total fatty acid content. It gives characteristics such as high viscosity, high miscibility, low iodine content, low freezing point, which make it an appropriate raw material to produce biodiesel [8,9].

This review describes the production of biodiesel from castor oil as feedstock. Aspects related to oil extraction, characteristics of oils to be used as a biodiesel feedstock, technologies to perform transesterification of vegetable oils, and biodiesel purification are described. Some of the most promising proposals recently used to increase yields, decrease costs, as well as limitations of biodiesel production processes, are discussed. Finally, the most common management practices to valorize biodiesel by-products are briefly presented.

\section{Vegetable Oils to Produce Biodiesel}

During biodiesel production it is necessary to consider the ecological and economic benefits during its production and its use as a biofuel. The biodiesel production cost depends greatly on the feedstock price. It is advisable to produce biodiesel in the same regions where the feedstock is located to decrease costs and environmental footprint related to feedstock transport [10].

The primary feedstock to produce biodiesel is raw vegetable oils and used cooking oils, as well as different animal grease. To produce biodiesel, several vegetable oils can be used such as rapeseed, soybean, cotton, peanut, corn, olive, sesame, safflower, and sunflower [11]. Some examples of tropical oily crops containing good quality oil that can be transesterified are Raphanus sativus (radish), Jatropha curcas (physic nut), Cyperus esculentus (tiger nut), Simmondsia chinensis (jojoba), Gratissima persea (avocado), Lupinus albus (white lupin), Caryocar brasiliense (pequi), the palm species Acrocomia aculeata, Mauritia flexuosa, Elaeis oleifera, Syagrus coronata, Attalea speciose, and R. communis (castor seeds) [12]. Table 1 shows some raw materials used in biodiesel production. However, the most common feedstock is raw vegetable oils extracted from energy and non-energy crops such as soybean, rapeseed, sunflower, coconut, and palm oil, which are cultivated around the world [13].

Table 1. Examples of oil-feedstock used in biodiesel production.

\begin{tabular}{|c|c|c|c|c|}
\hline $\begin{array}{l}\text { Feedstock Source } \\
\text { (Oil Content, \%) }\end{array}$ & Characteristics & Advantages & Disadvantages & Ref. \\
\hline $\begin{array}{l}\text { Castor beans } \\
\qquad(46-55)\end{array}$ & $\begin{array}{c}\text { Liquid at room temperature, } \\
\text { light yellow color, and slightly } \\
\text { pungent } \\
{ }^{*} \mathrm{US} \$ 824 / \text { tonne of oil }\end{array}$ & $\begin{array}{l}\text { Transesterification can be } \\
\text { performed at room } \\
\text { temperature } \\
\text { Miscible in alcohol } \\
\text { Non-edible } \\
\text { Low acid value } \\
\text { High flashpoint }\end{array}$ & $\begin{array}{c}\text { Generation of toxic solid waste } \\
\text { High viscosity } \\
\text { Decrease fuel atomization }\end{array}$ & {$[2,14]$} \\
\hline $\begin{array}{l}\text { Jatropha } \\
(34-60)\end{array}$ & 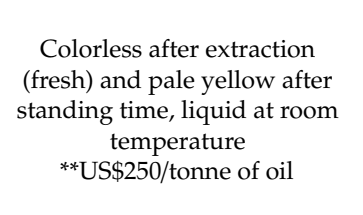 & $\begin{array}{l}\text { Biodiesel obtained is stable } \\
\text { during storage } \\
\text { Non-edible } \\
\text { High cetane number, good } \\
\text { oxidation stability, low } \\
\text { viscosity }\end{array}$ & $\begin{array}{c}\text { Engine corrosion due to free } \\
\text { fatty acids } \\
\text { Generation of toxic solid waste } \\
\text { High cloud point } \\
\text { Not suitable at low } \\
\text { temperature } \\
\text { High acid value }\end{array}$ & {$[15,16]$} \\
\hline $\begin{array}{l}\text { Soybean } \\
(12-22)\end{array}$ & $\begin{array}{l}\text { Fresh has a pale light color, } \\
\text { and dark after storage, liquid } \\
\text { at room temperature } \\
* * * \text { US } \$ 746 / \text { tonne of oil }\end{array}$ & $\begin{array}{l}\text { The yield of } 98 \% \text { crude } \\
\text { biodiesel in refined oils } \\
\text { High thermal stability } \\
\text { Low viscosity }\end{array}$ & $\begin{array}{l}\text { The high cost of production } \\
\text { Biodiesel production } \\
\text { in long-term is unsustainable } \\
\text { Edible } \\
\text { High acid value }\end{array}$ & {$[12,17]$} \\
\hline
\end{tabular}


Table 1. Cont.

\begin{tabular}{|c|c|c|c|c|}
\hline $\begin{array}{l}\text { Feedstock Source } \\
\text { (Oil Content, \%) }\end{array}$ & Characteristics & Advantages & Disadvantages & Ref. \\
\hline $\begin{array}{l}\text { Sunflower } \\
(38-50)\end{array}$ & $\begin{array}{c}\text { Refined has a clear and } \\
\text { vaguely yellowish-brown } \\
\text { color } \\
\begin{array}{c}\text { Liquid at room temperature } \\
* * * \text { US } \$ 689 / \text { tonne of oil }\end{array}\end{array}$ & Low viscosity & $\begin{array}{c}\text { Used to produce food and } \\
\text { fiber } \\
\text { Biodiesel production } \\
\text { in long-term is unsustainable } \\
\text { Edible } \\
\text { High acid value }\end{array}$ & {$[17,18]$} \\
\hline $\begin{array}{l}\text { Palm } \\
(18-40)\end{array}$ & $\begin{array}{c}\text { Semi-solid at room } \\
\text { temperature, reddish and clear } \\
\text { color, depending on extraction } \\
\text { source (pulp or kernel) } \\
* * * \text { US } \$ 535 / \text { tonne of oil }\end{array}$ & $\begin{array}{l}96 \% \text { yield of crude biodiesel } \\
\text { in refined oils } \\
\text { Cheap feedstock } \\
\text { Good oxidation stability } \\
\text { Acceptable ratio of } \\
\text { saponification } \\
\text { High flashpoint }\end{array}$ & $\begin{array}{c}\text { High cloud point } \\
\text { Conversion to biodiesel may } \\
\text { not be sustainable long term } \\
\text { Edible }\end{array}$ & {$[12,19]$} \\
\hline Used cooking oil & $\begin{array}{l}\text { Depends on the cooking } \\
\text { process can vary yellow to } \\
\text { dark brown, liquid at room } \\
\text { temperature } \\
* * * * \text { US } \$ 500 / \text { tonne of oil }\end{array}$ & $\begin{array}{l}\text { Low cloud point } \\
\text { Environmentally friendly } \\
\text { Low price of feedstock } \\
\text { Non-edible } \\
\text { High thermal stability }\end{array}$ & $\begin{array}{c}\text { High ratio of acid esterification } \\
\text { High ratio of saponification } \\
\text { High acid value }\end{array}$ & {$[18,20]$} \\
\hline
\end{tabular}

${ }^{*}$ Reported price from [21] (refined oil); ${ }^{* *}$ Reported price from [22]; ${ }^{* * *}$ Reported price from [23]; ${ }^{* * * *}$ Reported price from [24].

The preferred characteristics of oily raw materials to produce biodiesel are crop adaptability to grow under local conditions (precipitation, soil, latitude, temperature, etc.), availability, high oil content, appropriate composition, high adaptability with agricultural infrastructure, access to agricultural supplies (water, fertilizers, pesticides), potential to commercialize the different agricultural co-products generated as well as to obtain crops from marginal land [25]. R. communis meets most of the properties considered desirable to produce useful feedstocks in biodiesel production, except the high viscosity of oil that may limit its use. They are composed mainly of triglycerides and slight amounts of free fatty acids. Table 2 shows the most abundant fatty acids in vegetable oils (palmitic, oleic, and linoleic acids) from several sources. As mentioned above, castor oil, unlike other vegetable oils, has little variability in fatty acid content as compared to other species. In addition to ricinoleic acid, depending on its origin, R. communis may contain small quantities of oleic, linoleic, palmitic, stearic, and linolenic acids [26].

Table 2. Main fatty acids in vegetable oils used as feedstock in biodiesel production.

\begin{tabular}{cccccccccc}
\hline Oil & \multicolumn{9}{c}{ Fatty Acid Composition (wt\%) } \\
\hline & Saturated & \multicolumn{3}{c}{ Monounsaturated } & \multicolumn{3}{c}{ Polyunsaturated } \\
\hline & C14:0 & C16:0 & C18:0 & $\begin{array}{c}\text { C18:1 } \\
\text { cis-9 }\end{array}$ & C18:1* & C18:2 & C18:3 & Others \\
Castor & - & 1.1 & 1.0 & 3.3 & 87.7 & 4.7 & 0.7 & 1.5 & {$[27]$} \\
Jatropha & - & 12.80 & 6.20 & 39.94 & - & 45.40 & - & $<1.0$ & {$[16]$} \\
Soybean & - & 11.46 & 3.08 & 23.30 & - & 53.32 & 0.31 & 8.53 & {$[28,29]$} \\
Sunflower & 0.08 & 8.03 & 3.26 & 29.27 & - & 59.32 & - & 0.04 & {$[30]$} \\
Palm & 0 & 46.8 & 3.80 & 37.60 & - & 10.50 & - & 1.3 & {$[31]$} \\
Canola & - & 3.90 & 1.10 & 64.40 & - & 20.4 & 9.60 & 0.6 & {$[32]$} \\
\hline
\end{tabular}

C14:0 (Margaric acid); C16:0 (Palmitic acid); C18:0 (Stearic acid); C18:1 cis-9 (Oleic acid); C18:1 (Ricinoleic acid),

C18:2 (Linoleic acid); C18:3 (Linolenic acid); * Exclusive fatty acid present in castor oil.

Vegetable oils as a feedstock for biodiesel production is a promising source. However, most of them are used for food purposes and their use is restricted for this activity. Hence, castor oil for biofuel production shows several advantages over conventional edible oils. Due to its non-edible oil and its main fatty acid (ricinoleic acid) with hydroxyl groups which have a higher solubility in alcohols, it represents a great advantage to obtain methyl esters at low temperatures. 


\section{Oil Extraction Processes}

Technologies such as pressing extraction, solid-liquid extraction, and a combination of both are generally used to extract oils from seeds. Originally, technological development in processes to extract efficiently different vegetable oils was specifically to satisfy human consumption. However, during the last decades, non-edible oils have been used for producing other items, such as biodiesel from castor oil. Extraction method efficiency varies according to the moisture content in the seeds as well as extraction temperature.

For mechanical extraction, the oil is extracted using pressure and there is a wide variety of presses. When a screw press is used, the seeds can be preheated at $40-50{ }^{\circ} \mathrm{C}$ with the aim of decreasing the oil viscosity to enhance the extraction [33,34]. Other kinds of presses are the oil expellers, which could have an extraction efficiency as low as $8-14 \%$. In this case, oil is held in the "defatted cake". This problem increases with the oil viscosity and is critical in the case of castor oil. To solve this, expellers of dual-stage compression are used. After mechanical extraction, fresh oil may contain contaminants, such as fine pulp particles, which should be removed by decantation or filtration because their presence causes deterioration of the oil.

Vegetable oil extraction using solvents is commonly used at the industrial scale. This method offers up to $99 \%$ of extraction efficiency and high quality and purity of the oil, compensating the high costs of these extraction processes [35,36]. Between all solvents used to extract vegetable oils, hexane is the most used. After extraction, the solvent is removed by distillation and can be condensed and reused. However, in the case of castor seeds, the solvent can also extract toxic compounds such as ricin and contaminate the oil $[33,37]$.

Ethanol is an attractive solvent for oil extraction because it has low toxicity, is safe to manage, and can be produced from renewable sources. When ethanol is used for oil extraction, the distillation and solvent recovery steps can be replaced by a cooling process to form two phases, an oil micelle (the rich micelle) and an ethanol micelle (the lean micelle). Ethanol micelle is recycled for subsequent extractions. The rich micelle may contain up to $91 \%$ of oil, about $8 \%$ of ethanol, and $0.4 \%$ of free fatty acids. When the oil is used to produce biodiesel, the remaining ethanol may be an acyl acceptor in the transesterification reaction [38,39]. Danlami et al. [40] compared the efficiency of castor oil extraction using three different solvents (hexane, petroleum ether, and ethanol). The results obtained show that the maximum yield of castor oil extraction was obtained using methanol.

In recent years, processes with high extraction efficiency have been developed, such as supercritical fluids, ultrasound, and microwave [36,39,40]. Oil extraction using supercritical $\mathrm{CO}_{2}$ as a solvent is an attractive alternative as it is non-toxic, easy to obtain, inexpensive, and non-flammable. Additionally, the refining steps are simpler than those of conventional processes, because some steps, such as distillation are not necessary. However, the main inconvenience of this process is that it requires a high capital investment and energy consumption causing high production costs [37]. For instance, Del Valle et al. [41] performed an economic analysis focused on operational cost and mass transfer in a process of oil extraction from pre-pressed oleaginous seeds, using supercritical $\mathrm{CO}_{2}$ as a non-conventional solvent. Likewise, Nunez and del Valle [42] calculate the production cost in an industrial vessel during oil extraction using supercritical $\mathrm{CO}_{2}$. They calculate a total $\mathrm{CO}_{2}$ production cost from $3.53 \%$ to $4.31 \%$ using $3000 \mathrm{~kg} / \mathrm{h}$ of $\mathrm{CO}_{2} /$ vessel. In addition, when they increase to $6000 \mathrm{~kg} / \mathrm{h}$ of $\mathrm{CO}_{2} / \mathrm{vessel}$ $\mathrm{CO}_{2}$ in the system, the total cost only increases by $1.33 \%$. Nevertheless, so far it is not possible to establish a fixed cost for supercritical $\mathrm{CO}_{2}$ on castor seed oil extraction, as to calculate the cost, several parameters need to be considered. Some of the most important are vessels (unit number and capacity), scale (laboratory, pilot or industrial), $\mathrm{CO}_{2}$ characteristics (density, $\mathrm{kg}$ used/kg of feedstock, superficial velocity, residence extraction time), among others.

The use of ultrasound-assisted extraction promotes the breakdown of cell walls in mashed castor seeds, facilitating the release of intracellular material and favoring the mass transport of solvent [4]. In microwave-assisted extraction, the quickly generated heat creates pressure forces in the interior of the biological matrix, producing high-quality extracts and high recovery efficiency of oil. It has been 
reported that this type of process has allowed extracting higher amounts of soybean and rice oil in less time (20 $\mathrm{min}$ ) as compared to conventional solvent extraction [43]. According to Ali et al. [34], considering the power consumption during vegetable oil extraction, microwave-assisted extraction (MAE) is more efficient than mechanical (22.6\%), solvent (36.3\%), or ultrasonic extraction $(10 \%)$.

Although it has been reported that the most efficient method for the extraction of castor oil is through organic solvents such as hexane, toluene, petroleum ether, or heptane, the cost of the process increases the final biodiesel cost. Due to this reason, so far, cold-pressing has been the best method from the process point of view. This method has several advantages, such as low investment cost, low labor, continuous oil extraction and low or no impact on the chemical characteristics of the oil. Likewise, similar yields have been reported for those obtained using a solvent extraction process.

\section{Transesterification}

Among all the methods for the production of biodiesel using vegetable oils as a feedstock, the most used is a transesterification reaction, where triglycerides (TGA) are transformed into fatty acid methyl esters (FAMEs) with a chemical or biological catalyst. Transesterification reaction usually has been used to produce biodiesel from different vegetable oils including castor oil. Transesterification is a key step of biodiesel production and three important conditions that need to be considered for this step are temperature, reaction time, and catalysts [44]. In addition, triglycerides transesterification can be performed using methanol (FAMEs) or ethanol (FAEEs) in the presence of different types of catalysts, such as sodium hydroxide, potassium hydroxide, or sulfuric acid. Nevertheless, the use of methanol presents some advantages, for example the reaction time is shorter, and the temperature is smaller. For instance, Meneghetti et al. [45] evaluated methanolysis and ethanolysis for biodiesel production using castor oil as a feedstock. They reported that the high yield of biodiesel production using methanol was $90 \%$ with $1 \mathrm{~h}$ of reaction time at $60^{\circ} \mathrm{C}$. However, when they used ethanol the reaction time and temperature increased up to $5 \mathrm{~h}$ and $80^{\circ} \mathrm{C}$, respectively. They attributed the catalytic difference due to water molecules production when the active species are formed in the presence of hydroxide groups because they can form soaps or esters provoking an important decrease in biodiesel yield. Likewise, biodiesel production through ethanolysis shows more problems during the by-product separation process [46].

\subsection{Chemical Processes: Homogeneous and Heterogeneous Catalysis}

\subsubsection{Homogeneous Catalysis}

In this method, an acid or alkaline solution is used as a catalyst. Alkaline catalysts such as potassium hydroxide and potassium methoxide are normally used for the production of biodiesel as they are more efficient and cheaper than acids. Alkaline catalysts can give high reaction yields (over 97\%) in relatively short periods (from $10 \mathrm{~min}$ to $2 \mathrm{~h}$ ), under moderate temperatures $\left(25-70^{\circ} \mathrm{C}\right)[10,12,47]$. In the reaction, nucleophilic alkoxide ion attacks the electrophilic part of the carbonyl group present in a triglyceride molecule. Figure 1 shows the breakdown of triglycerides using microwaves and alkaline catalyst. In the first stage, a tetrahedral intermediate is produced when the alkoxide ion is attached to the carbonyl group of triacylglycerol molecules. Subsequently, the tetrahedral intermediate reacts with alcohol and the alkoxide ion is regenerated, and finally during the last step tetrahedral intermediate is rearranged, to obtain fatty acid alkyl esters (FAAE) and diacylglycerol (DAG) molecules. These mechanisms occur for the breaking of each fatty acid and at the end, three esters of fatty acids (FAEs) and glycerol are formed [48]. 


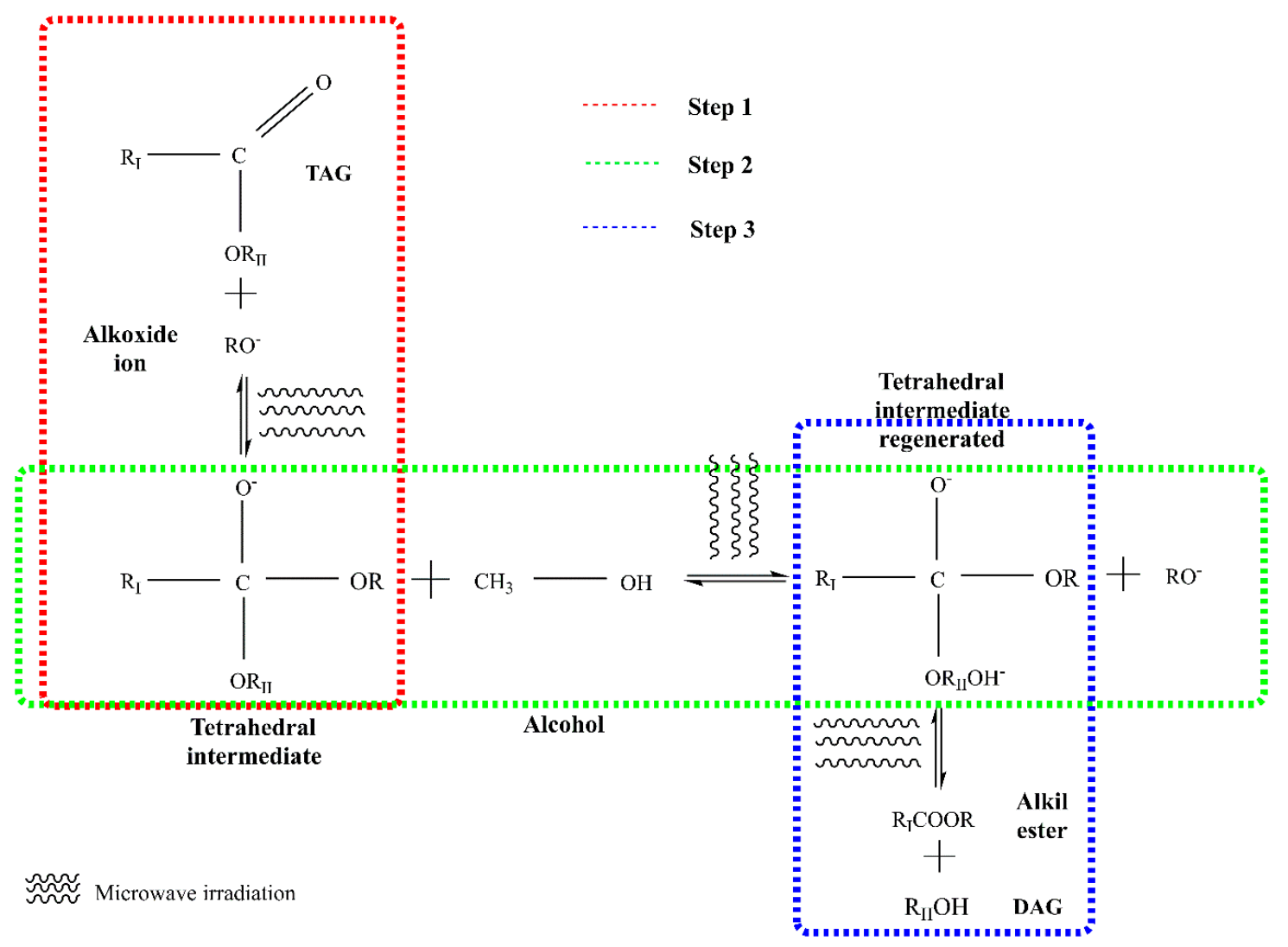

Figure 1. Sequence of the transesterification reaction of oil using alkaline catalysis and microwaves (modified from [49]). TAG: Triglyceride, DAG: Diglyceride, $\mathrm{R}_{\mathrm{II}}$ : glyceride, $\mathrm{R}_{\mathrm{I}}$ : carbon chain fatty acid; R: alkyl group of alcohol.

The alkaline-catalyzed transesterification requires raw materials with moisture content lower than $0.3 \%(\mathrm{w} / \mathrm{w})$ and less than $0.05 \%$ free fatty acids (FFA) to avoid the formation of soap, which hinders the separation of biodiesel from the glycerol and other by-products. Table 3 shows different works using alkaline transesterification to produce biodiesel. In a study using rapeseed oil, it was observed that the basic transesterification may produce yields of up to $95 \%$ in reaction time shorter than 2 min. For higher reaction time, the saponification occurs. This means that the transesterification reaction must be stopped at the exit point of the reactor to avoid the formation of soap, which could cause significant losses [41]. Therefore, the most important step during acid catalysis is protonation reaction from the carbonyl group in the triglyceride molecule as well as the reaction between alcohol and protonated group to create a tetrahedral intermediate [42]. Acid catalysis generally requires sulfuric acid, sulfonic acid, or hydrochloric acid. Acid catalysis is considered more appropriate to transesterify vegetable oils with a high amount of free fatty acids (FFA) because no soap is produced. However, it requires prolonged reaction times as well as high amounts of alcohol [43]. For raw materials rich in FFA, the use of two catalytic steps is recommended, first acid esterification of fatty acids (sulphuric acid, with a reaction time from 4 to $69 \mathrm{~h}$, with a yield up to $99 \%$ ), followed by alkaline transesterification of triglycerides. This combination allows reaching conversions near to $100 \%[1,22,44]$. 
Table 3. Alkaline transesterification used in biodiesel production from castor oil.

\begin{tabular}{|c|c|c|c|c|}
\hline Method & Conditions & Yield & Biodiesel Features & Ref. \\
\hline $\begin{array}{c}\text { Alkaline } \\
\text { transesterification }\end{array}$ & $\begin{array}{c}\text { 1:12 oil:methanol, potassium } \\
\text { hydroxide } 1.25 \% \mathrm{wt} \\
60^{\circ} \mathrm{C} \\
60 \mathrm{~min}\end{array}$ & $94.9 \%$ & $\begin{array}{l}\text { High density and flashpoint } \\
\text { Low sulfur content } \\
\text { Yellow color }\end{array}$ & [44] \\
\hline $\begin{array}{c}\text { Alkaline } \\
\text { transesterification }\end{array}$ & $\begin{array}{c}\text { 1:5.4 oil:methanol, potassium } \\
\text { hydroxide } 0.73 \% \mathrm{wt} \\
64^{\circ} \mathrm{C} \\
2.5 \mathrm{~h}\end{array}$ & $97.8 \%$ & - & [45] \\
\hline $\begin{array}{c}\text { Alkaline } \\
\text { transesterification }\end{array}$ & $\begin{array}{c}\text { 1:8.24 oil:methanol, potassium } \\
\text { hydroxide } 1.45 \% \mathrm{wt} \\
35.5^{\circ} \mathrm{C} \\
40 \mathrm{~min}\end{array}$ & $93.2 \%$ & Low acid value & [50] \\
\hline $\begin{array}{c}\text { Alkaline } \\
\text { transesterification }\end{array}$ & $\begin{array}{c}\text { 0.29:1 oil:ethanol, potassium } \\
\text { hydroxide } \\
1 \% \mathrm{wt} \\
62.5^{\circ} \mathrm{C} \\
226 \mathrm{~min}\end{array}$ & $85 \%$ & High density and flashpoint & [51] \\
\hline $\begin{array}{c}\text { Alkaline } \\
\text { transesterification }\end{array}$ & $\begin{array}{c}\text { 1:6 oil:ethanol } \\
\text { Potassium hydroxide } \\
1 \% \mathrm{wt} \\
55-65^{\circ} \mathrm{C} \\
2-8 \mathrm{~h}\end{array}$ & $43.3-74.1 \%$ & $\begin{array}{l}\text { Low acid value } \\
\text { High flashpoint }\end{array}$ & [50] \\
\hline
\end{tabular}

\subsubsection{Heterogeneous Catalysis}

Heterogeneous catalysis is an alternative to produce biodiesel without producing aqueous wastes. This process makes it possible to recover, regenerate, and reuse the catalyst. It can be performed in batch or continuous processes without needing additional purification steps, and high yields of high-quality biodiesel can be obtained. A key advantage of this catalysis is that it allows performing the esterification of free fatty acids and triglyceride transesterification simultaneously, and thus decreases time and energy consumption $[52,53]$. Solid catalysts are commercially available for heterogeneous esterification and transesterification, such as those of families of Amberlyst ${ }^{\circledR}$ and Nafion ${ }^{\circledR}$. Different solid acids such as mesoporous silica with sulfonic acid, carbon modified metal oxides, heteropolyacids, metal-incorporated porous oxides, zeolites, ion exchange resins, inorganic-oxide solid acids, and supported noble metal oxides have been synthesized to use as a catalyst during biodiesel production using low-quality oils [1,54].

$\mathrm{Du}$ et al. [55] reported biodiesel production with heterogeneous catalysts using NaY zeolite as support and $\mathrm{La}_{2} \mathrm{O}_{3}$ as a catalyst. The result showed that the catalyst has good reusability and strength, two essential characteristics for industrial scale-up. The optimal conditions that they found to obtain a yield of $84.6 \%$ were using $10 \%$ of catalyst concentration, a molar ratio of 15:1 ethanol:oil, $50 \mathrm{~min}$ of reaction time and $70{ }^{\circ} \mathrm{C}$ as reaction temperature. Likewise, Baskar et al. [56] investigated Ni-doped $\mathrm{ZnO}$ nanocatalyst for biodiesel production using castor oil as a feedstock. The results obtained show a $95.20 \%$ yield under optimal conditions (1:8 oil:methanol, $11 \%$ of catalyst, $60 \mathrm{~min}$, and $55^{\circ} \mathrm{C}$ ). Additionally, they observed that the catalyst can be used for three cycles without losing its efficiency.

Moreover, heterogeneous catalyst has been used for biodiesel production using several vegetable oils. For instance, Sun et al. [53] reported that heterogeneous catalysts such as potassium oxide $\left(\mathrm{K}_{2} \mathrm{O}\right)$ and potassium aluminate $\left(\mathrm{K}_{2} \mathrm{Al}_{2} \mathrm{O}_{4}\right), \mathrm{Mo}-\mathrm{Mn} / \gamma-\mathrm{Al}_{2} \mathrm{O}_{3}-\mathrm{MgO}$, potassium carbonate $\left(\mathrm{K}_{2} \mathrm{CO}_{3}\right)$, magnesium aluminide $(\mathrm{Mg}-\mathrm{Al})$ calcined hydrotalcite, $\mathrm{CaO}-\mathrm{MoO}_{3}-\mathrm{SBA}-15$, $\mathrm{Li} / \mathrm{ZnO}, \mathrm{KF} / \mathrm{Ca}-\mathrm{Al}$ hydrotalcite, $\mathrm{KF} / \mathrm{Ca}-\mathrm{Mg}-\mathrm{Al}, \mathrm{CaO} / \mathrm{KI} / \gamma-\mathrm{Al}_{2} \mathrm{O}_{3}$, and aluminum-silicon $(\mathrm{Al} / \mathrm{Si})$ supported in potassium carbonate $\left(\mathrm{K}_{2} \mathrm{CO}_{3}\right)$ have been used. Recently, a process was developed using sodium methoxide $\left(\mathrm{CH}_{3} \mathrm{ONa}\right)$ formed through crystallization with dimethyl carbonate (DMC) as a catalyst in biodiesel production using canola oil. This process helps to obtain conversions above $95 \%$ without generating glycerol as a by-product, however, the efficiency of the catalyst is reduced at each reaction cycle [57]. 
Some vegetal derived materials have also been proposed as catalysts. For example, Li et al. [20] tested a solid acid catalyst $\left(\mathrm{RHC}-\mathrm{SO}_{3} \mathrm{H}\right)$ obtained from rice husk activated carbon (RHC) with concentrated sulfuric acid. This catalyst presented high catalytic performance and high stability in the biodiesel production process using waste cooking oil.

One of the main disadvantages of heterogeneous catalysis is the low reaction rate, caused mainly by the use of high amounts of catalysts and methanol under severe operating conditions which affects the stability of catalysts [1].

\subsubsection{Parameters Affecting Transesterification Reactions}

The main parameters which influence the chemical transesterification are temperature, alcohol-triglyceride ratio, reaction time, catalyst, moisture, and free fatty acid content [58]. Table 4 shows the effect of several parameters during biodiesel production.

Table 4. Effect of main parameters on transesterification.

\begin{tabular}{|c|c|c|}
\hline Parameter & Effect & Ref. \\
\hline Temperature & $\begin{array}{l}\text { Depending on the catalyst, temperature affects the reaction rate. } \\
\text { The temperature range is } 25-120^{\circ} \mathrm{C} \text {, being optimal around } 60^{\circ} \mathrm{C}\end{array}$ & [59] \\
\hline Alcohol triglyceride molar ratio & $\begin{array}{c}\text { The stoichiometric ratio needs a 3:1 alcohol:oil molar ratio to produce } \\
\text { three moles of alkyl esters of fatty acids and one mole of glycerol. } \\
\text { To perform the best transesterification reaction is necessary for } \\
\text { an alcohol excess to promote the product's equilibrium. However, } \\
\text { residual alcohol interferes during glycerol separation from biodiesel } \\
\text { because it is highly soluble in alcohol }\end{array}$ & [2] \\
\hline Time & $\begin{array}{l}\text { Has been reported that longer reaction times increase the conversion of } \\
\text { fatty acids to fatty acid methyl esters }\end{array}$ & {$[51]$} \\
\hline Catalyst & $\begin{array}{l}\text { Alkaline catalysts increase the reaction rates in comparison with an acid } \\
\text { catalyst. However, when the vegetable oil has a high free fatty acid } \\
\text { content as well as high water content, an acid transesterification is } \\
\text { recommended because soap is not formed }\end{array}$ & {$[60]$} \\
\hline Moisture content & $\begin{array}{l}\text { For alkaline catalysis, both compounds (triglycerides and alcohol) need } \\
\text { to be anhydrous, due to water induces saponification }\end{array}$ & {$[44]$} \\
\hline Content of free fatty acids & $\begin{array}{l}\text { In the alkaline catalysis, the content of free fatty acids should be as low } \\
\text { as } 0.5 \% \mathrm{w} / \mathrm{w} \text { of oil, to avoid the formation of soaps. }\end{array}$ & {$[61]$} \\
\hline
\end{tabular}

\subsection{Biological Transesterification}

When the feedstock to produce biodiesel is rich in free fatty acids (for example waste cooking oils), it is necessary to perform acid-catalyzed esterification before alkaline transesterification. However, this can cause corrosion in equipment and need the addition for chemical compounds to neutralize the biodiesel, increasing the costs of biodiesel production. Consequently, environmental pollution also increases. Biological catalysis is a suitable alternative to these problems. The use of biological agents as catalysts in biodiesel production has the advantages of operating under mild reaction conditions, decreasing the emissions of pollutants, and favoring the separation of glycerol [10]. Generally, biological catalysis can be performed using free or immobilized enzymes, as well as microbial cells. Table 5 shows some advantages and disadvantages of these systems. So far, whole-cell systems are the most accepted and used biocatalyst to perform biological transesterification as they have more advantages as compared to free or immobilized enzymes.

An example of this type of transesterification for the production of biodiesel using castor oil as raw material is the work carried out by Kumar et al. [62]. The optimal conditions to obtain a biodiesel yield of $78 \%$ were $6: 1$ alcohol:molar oil ratio, $10 \%$ of the immobilized enzyme for $24 \mathrm{~h}$ at $50{ }^{\circ} \mathrm{C}$. Besides, they found that the immobilized enzyme can be reused by 12 cycles with a biodiesel yield of $70 \%$ after six cycles. Likewise, Andrade et al. [63] performed a simulation of a full biodiesel process using biological catalysis (free and immobilized enzyme) and castor oil as a feedstock. The observed results show that when they used free enzyme, minimization in the enzyme flow increases the profit in the transesterification reaction. In this process, optimal conditions in the reactor to obtain a biodiesel 
yield of $93 \%$, were $0.3 \% \mathrm{w} / \mathrm{v} / \mathrm{kg}$ of castor oil, methanol:oil ratio equal to 9 , and $36.4{ }^{\circ} \mathrm{C}$. On the other hand, when they used immobilized enzyme, optimal conditions to get $99.9 \%$, were $50{ }^{\circ} \mathrm{C}$ of temperature reaction for $4 \mathrm{~h}$ using methanol:oil ratio of $17.6 \% \mathrm{w} / \mathrm{v} / \mathrm{kg}$ of castor oil. Even though the biodiesel yield was higher using the immobilized enzyme, the total cost of the process was higher than when they used a free enzyme to perform a transesterification reaction. The above fact was because of an increase in temperature and reaction time to perform a transesterification reaction. The above fact was because of an increase in temperature and reaction time to perform a transesterification reaction, as well as due to higher consumption of methanol:oil ratio.

Table 5. Biocatalysis used in biodiesel production.

\begin{tabular}{|c|c|c|c|}
\hline Biocatalyst & Advantages & Disadvantages & Ref. \\
\hline Free enzymes & $\begin{array}{l}\text { Low energy consumption, highly selective, efficient } \\
\text { catalytic activity, environmentally friendly }\end{array}$ & $\begin{array}{l}\text { Unstable } \\
\text { Difficult to be reused } \\
\text { Costly }\end{array}$ & [63] \\
\hline Immobilized enzymes & Stability and reusability & $\begin{array}{c}\text { Costly } \\
\text { Low reaction rate } \\
\text { Extra steps during the recovery process } \\
\text { Loss of enzyme activity }\end{array}$ & [62] \\
\hline Whole-cell & $\begin{array}{l}\text { Simple preparation } \\
\text { Purification and immobilization not required }\end{array}$ & $\begin{array}{c}\text { Low activity } \\
\text { Easy inactivation } \\
\text { Low rate of recovery and reusability }\end{array}$ & {$[64]$} \\
\hline
\end{tabular}

Likewise, other biological processes have also been reported. Jiang et al. [65] used a Pickering emulsion stabilized with lipase mixed with mesoporous organosilica (LP@PE ${ }^{\circledR}$ ) for biodiesel production using Jatropha curcas oil. With this catalytic system, it was possible to obtain a yield of biodiesel production of $95 \%$ when oleic acid was used and $87.1 \%$ when Jatropha curcas oil was used. The yield could be maintained above $73 \%$ during the 15 reaction cycles. Yan et al. [10] designed a recombinant yeast (Pichia pastoris sp.) with the functional intracellular expression of lipase from Thermomyces lanuginosus to improve the conversion of waste cooking oil into fatty acid methyl esters. They reported that enzyme produced by the modified strain contributed to the oil conversion, obtaining a transesterification efficiency of $82 \%$.

\subsection{Transesterification Using Ultrasound}

Ultrasound is defined as the sound waves which have a higher frequency than that sensed by humans. The frequency ranges of ultrasound waves are from $20 \mathrm{kHz}$ to $100 \mathrm{MHz}$. When high-frequency sound passes through the reaction system, molecular spaces may stretch and compress, causing the vibration and cavitation of the reaction system [66]. Ultrasonic cavitation has a specific effect to increase the temperature, providing mechanical energy to mix the reaction media as well as energy activation to start the reaction. Cavitation forms bubbles, which collapse and break the boundary of two liquid phases. This also produces emulsification by the effect of ultrasonic jets that pass from liquid to liquid. These phenomena increase the reaction rate and biodiesel yield [30,67].

The ultrasound applied to transesterification is attractive because reactors for transesterification are safe and not complex. Ultrasonically assisted transesterification has been tested using different feedstock showing its beneficial effects, such as the increase of reaction rates and yields, and the decrease of alcohol:oil molar ratio and operating temperature [68]. An example of this process to produce biodiesel from castor oil is the research performed by Sabzimaleki et al [69]. They optimized several ultrasound-assisted transesterification reactions to produce biodiesel from castor oil obtaining a reaction yield of $87 \%$ in optimal conditions with a wave ultrasonic amplitude of $64 \%, 0.73 \%$ of an ultrasonic cycle, and a 1:8.15 oil:methanol ratio. The author reported that reaction time is the most important parameter during the transesterification reaction to obtain the high title of biodiesel. Likewise, it is possible to perform the esterification and transesterification in the same reactor using ultrasound. This does not change the characteristics of the product. The combination of ultrasound with co-solvents during extraction allows us to increase oil solubility in alcohol and increase biodiesel 
yield. The most common co-solvents are benzene, hexane, tetrahydrofuran, chloroform, petroleum ether, and dichloromethane $[67,70]$.

\subsection{Membrane Reactors}

Known as a reactive separator, membrane reactors are types of equipment in which chemical reactions and separations can be performed simultaneously [48]. According to Shuit et al. [71], membrane separation technologies applied to the production of biodiesel are based on three main principles: separation based in oil droplet size, catalytic membrane characteristics, and pervaporation. Additionally, the interest to use membrane reactors for producing and refining biodiesel has increased significantly in recent years as these systems provide high purity and product quality, as well as better yields than conventional processes [51,72]. Membrane reactors can be used for different activities, such as to improve contact between the reactants and catalysts, selective removal of products from mixture reaction and take control during the addition or removal reactants [73]. This technology has been successfully applied in the transesterification of vegetable oil using a ceramic membrane reactor [74]. Transesterification reactions in membrane reactors can be reversible, and products should be removed to increase reaction yields. The use of membrane reactors can limit the route of non-reacted oils with product mixture, allowing an increase in biodiesel quality during its production using low-quality feedstocks.

\subsection{Microwave}

Electromagnetic waves between $300 \mathrm{MHz}$ and $300 \mathrm{GHz}$ are known as microwaves. In transesterification processes, these microwaves promote the molecular rotation of the compounds, improving their molecular interaction as well as dissipating their energy. These actions promote better heat transfer in the reaction mixture without affecting the molecular structure of formed products [75]. In general, catalytic processes using microwaves promotes directly and homogeneously the absorption of energy in the material that is irradiated. One of the main advantages that this process has compared to conventional heating systems, is the elimination of temperature gradients since the heating is homogeneous and selective due to the specific characteristics of the reaction mixture. During the last decade, catalytic processes using microwaves have been increasing because it is considered a low-cost, environmentally friendly technology and the reaction times are shorter, making the energy consumption in the process less $[31,76]$.

When microwaves are used, esterification and transesterification of castor oil are improved by the overheating in the reaction mixture, because the solvent is heated quickly above its boiling point, improving the transesterification reaction homogeneously. The above fact contributes greatly to increase the biodiesel yield [77]. The reaction time of transesterification can be increased up to 2-fold of magnitude when the microwave is applied. For instance, Thakkar et al. [77] evaluated a hybrid ultrasound-microwave system to produce biodiesel from castor oil. They produced biodiesel using $1.74 \%$ of $\mathrm{KOH}$ as a catalyst at $43{ }^{\circ} \mathrm{C}$ in a 350:1 methanol:oil ratio during $30 \mathrm{~min}$ of reaction time. They performed an energy analysis of the transesterification process. The obtained results show a total energy consumption of $8 \mathrm{~W}$ with a decrease of 6 -fold during the ultrasound process and only a 1.5-fold decrease when the microwave process was used. However, in comparison with a normal mechanical stirrer process, energy consumption can decrease by more than 50\% using this hybrid system (195 and $80 \mathrm{Wh}$, respectively). Likewise, the authors observed a yield increase of 2-fold in transesterification reaction, from $40 \%$ to $93 \%$. In conclusion, the authors affirm that in laboratory-scale this type of system can decrease four times with total energy consumption of $7.9 \mathrm{Wh}$, in comparison with the obtained using mechanical stirring ( $30 \mathrm{Wh}$ ). However, other types of effects will need to be analyzed, for instance, in this type of process, there are no changes in the reaction rate related to non-thermal effects. Moreover, in some works, microwave process decreases the activation energy of triglycerides and methanol due to the increase of dipolar polarization $[75,78,79]$. 
Different catalysts and catalytic processes have been evaluated to improve the conversion of fatty acids to methyl esters. Some of them have shown to be very efficient. Nevertheless, initial investment and the energy consumption during the conversion process are very high, which makes them unaffordable since it increases the total process cost and consequently the final biodiesel cost. Thus, homogeneous and heterogeneous catalysis is a viable method to produce biodiesel. However, between these two methods, heterogeneous catalysis has larger advantages such as reuse of the catalyst and low cost, some heterogeneous catalyzers can perform esterification and transesterification simultaneously, decreasing the stages of the process. Likewise, it contributes to improving product separation and, in some cases, depending on the catalysis conditions, a final stage of biodiesel washing is not necessary.

\section{Castor Oil Biodiesel Production and Features}

Castor oil is a light yellow and slightly pungent liquid, that is used in several industries around the world. Some of these industries are pharmaceutical, cosmetic, chemical, among others. However, in recent years this non-edible vegetable oil has been investigated to produce biofuels, specifically biodiesel. The above is due to physicochemical, chemical, and physical characteristics of castor oil (Table 6) give to biodiesel when this is used as a feedstock.

Table 6. Main characteristics of raw castor oil.

\begin{tabular}{cccc}
\hline Parameter & Zhang et al. [80] & Molefe et al. [81] & Kaur and Bhaskar [82] \\
\hline Acid value $/\left(\mathrm{mg}^{-} \mathrm{g}^{-1}\right)$ & 1 & 2.07 & $<4$ \\
Saponification value $/\left(\mathrm{mg}^{-} \mathrm{g}^{-1}\right)$ & 180 & 175 & 178 \\
Iodine value $(\mathrm{g} / 100 \mathrm{~g})$ & 86 & 84 & 85 \\
Refractive index $(\mathrm{n} 20 \mathrm{D})$ & 1.48 & 1.48 & 1.47 \\
Relative density $\left(\mathrm{g} / \mathrm{cm}^{3}\right)$ & 0.956 & 0.961 & 0.965 \\
Flashpoint $\left({ }^{\circ} \mathrm{C}\right)$ & 322 & 145 & 229 \\
Specific heat $(\mathrm{kJ} / \mathrm{kg} / \mathrm{K})$ & $\mathrm{nd}$ & 0.089 & 0.089 \\
Ricinic acid $(\% \mathrm{wt})$ & 88 & 89.5 & $87-90$ \\
Oleic acid $(\% \mathrm{wt})$ & 7 & 3 & $2-7$ \\
Linoleic acid $(\% \mathrm{wt})$ & 5 & 4 & $1-5$ \\
Linolenic acid $(\% \mathrm{wt})$ & 1 & 0.3 & nd \\
\hline
\end{tabular}

nd: not determined.

The process to produce biodiesel from oilseeds usually starts with oil extraction using a mechanical press or solvents. Figure 2 shows a general scheme for castor oil extraction. To perform mechanical oil extraction from castor beans it is necessary to consider the high oil viscosity. On the contrary, this is not necessary if the oil is extracted with solvents, but an evaporation step would be needed to recover the solvent. After extraction, different refining steps such as filtration, centrifugation, deodorization, discoloration, or winterization would be necessary to improve biodiesel quality.

To control the enzymatic and oxidative degradation of crude oil, refining steps are required. The main refining steps are degumming, neutralization, bleaching, and drying. In degumming, phosphatides are removed by acidification, precipitation, and sedimentation. Neutralization allows the elimination of fatty acids. The bleaching step is mainly used to remove color by clay adsorbing oil, and then separated by centrifugation. Finally, the moisture can be removed by heating $[20,83]$. Biodiesel is produced through different processes, such as oil blending, microemulsions, and transesterification. Among them, the most common process is through transesterification reaction, and it is used to transform vegetable oils into biodiesel [84]. Figure 3 shows a general scheme of transesterification reaction to obtain biodiesel using castor oil. As a definition, transesterification is the "reaction of a lipid with an alcohol to form esters and glycerol" [48]. Methyl or ethyl esters (biodiesel) from vegetable oils are obtained through chemical or biological catalysis. Therefore, it is necessary to perform separation by centrifugation or decantation to improve the recovery of all products (biodiesel, 
solvent, and glycerol). In this sense, with the separation step, the presence of impurities decreases, helping to decrease the downstream cost during its purification. Finally, residual alcohol is recovered by distillation and is recycled to the transesterification process, which contributes to the feasibility of the entire process $[2,44]$.

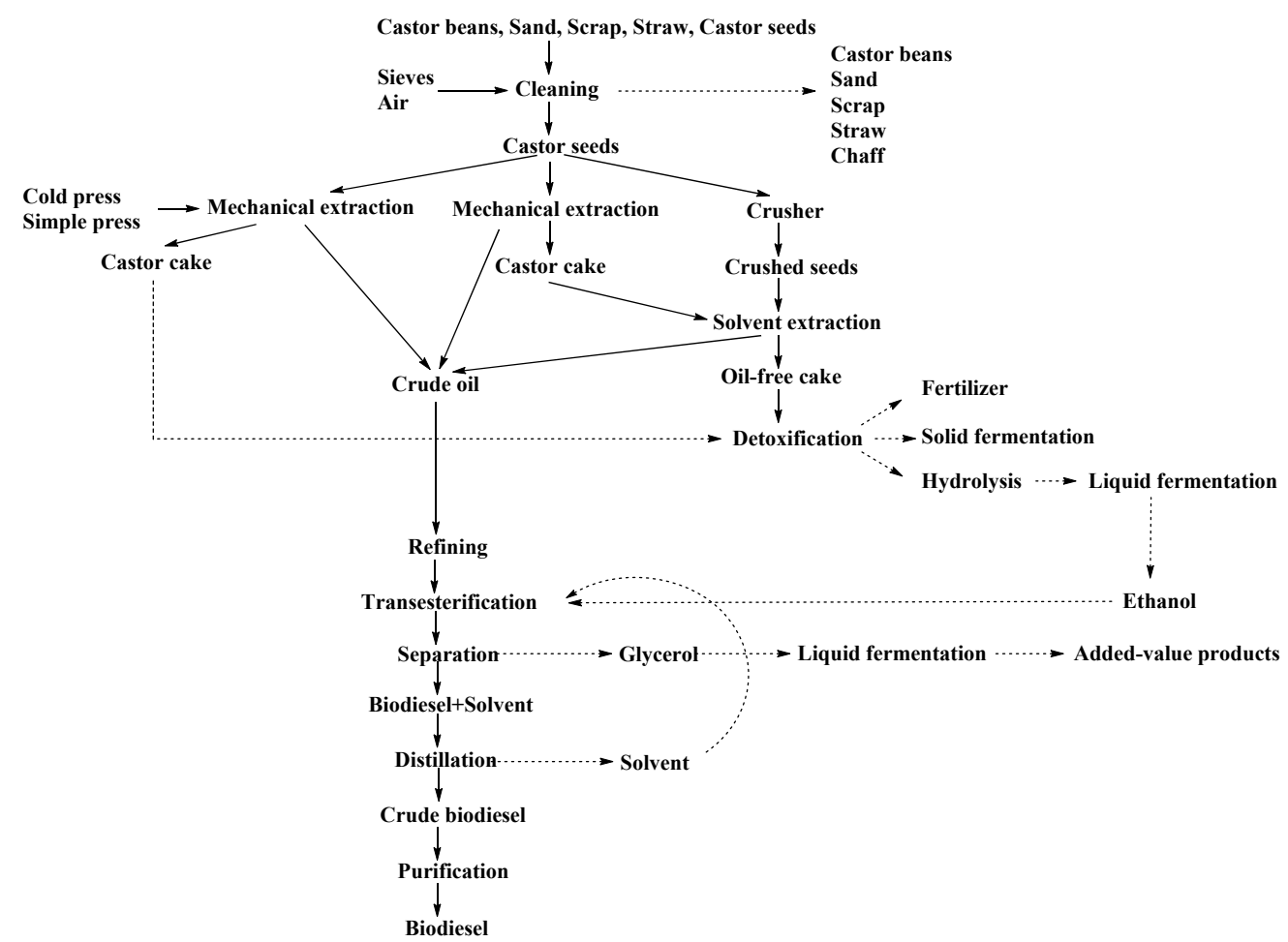

Figure 2. General scheme to produce biodiesel from castor oil (adapted from [40,46]).

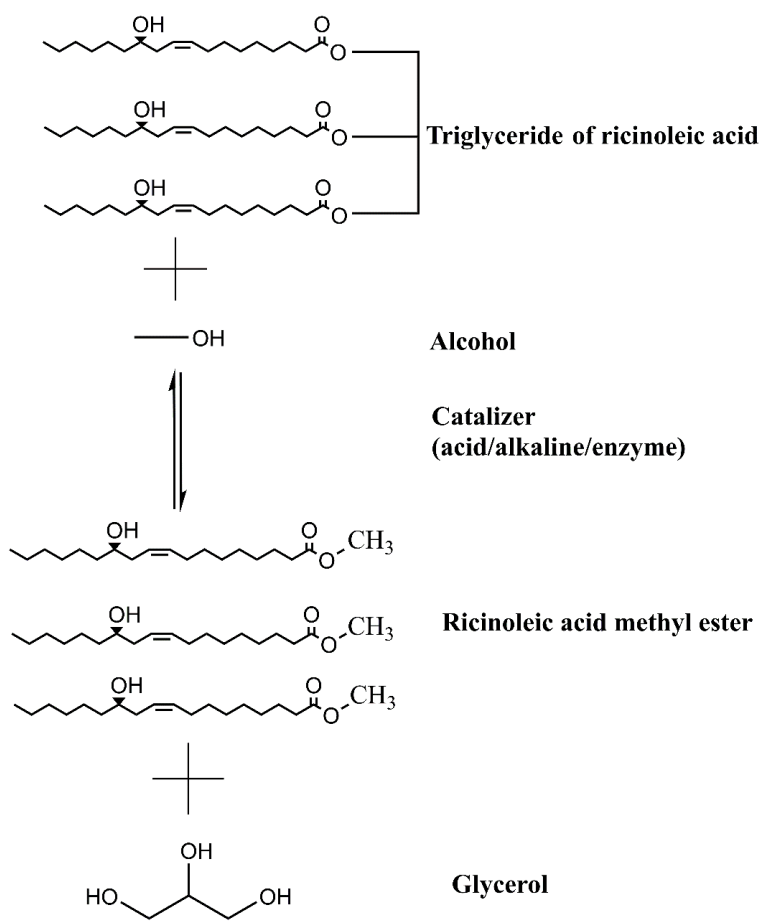

Figure 3. Transesterification reaction during biodiesel production using castor oil as feedstock. 
Once the biodiesel is obtained, this can be used directly in a neat form $(100 \%)$ or blended with petrodiesel (25\%, 50\%, and $75 \%$, commonly). However, to ensure that the biodiesel or the blend does not represent a potential risk to the vehicle engine, biodiesel needs to conform to specific parameters established by different entities such as Standard Specification for Biodiesel Fuel Blend Stock (B100) for Middle Distillate Fuels (ASTM D 6751-06a) or European Committee for Standardization for biodiesel (EN 14214). Table 7 shows key parameters for biodiesel from castor oil and its comparison with the two standards mentioned above, as well as with petrodiesel characteristics.

Castor oil biodiesel has different advantages in comparison with fossil diesel, the most significant are biodegradable, non-toxic, renewable, it can be used alone, low greenhouse gas emission $(80 \%$ less carbon dioxide emissions and not sulfur content), and during combustion it decreases the unburned and aromatic hydrocarbons. Nevertheless, one of the main disadvantages that castor oil biodiesel has is related to its high viscosity, as compression ignition is difficult, especially at low temperatures, which causes a decrease of volatility and as consequence of burning ratio, without a complete burn provoking deposits. The above facts harm the injection system, as well as blocking the fuel filter [85]. Likewise, high values of density can cause some problems in the injection system as well as in the fuel pump. For instance, Tesfa et al. [86] evaluated viscosity and the density effect of different blends of biodiesel produced from different vegetable oils on fuel filters and fuel pumps. They found that when the viscosity and density values increase, biodiesel flow into the fuel filter decreases through time. The above fact can be attributed to the high flow struggle into the filter due to the high viscosity and density. Then, the decrease of biodiesel inlet flow to the vehicle engine will be traduced as a loss of power generation. Nonetheless, until now no research has been performed to analyze the castor oil biodiesel split-up at low temperatures. One of the reasons can be the low freezing point that this biofuel has. However, it has been reported that the addition of cold flow improvers can help to decrease several problems caused by low temperature. In general, the cold flow improvers are polymeric materials such as ethylene-vinyl acetate, polymethacrylates, and polyacrylates. The effect of these compounds is to prevent the nucleation of crystal wax through the link with the biodiesel hydrocarbon chain [87].

Table 7. Main characteristics of biodiesel produced using castor oil as a feedstock.

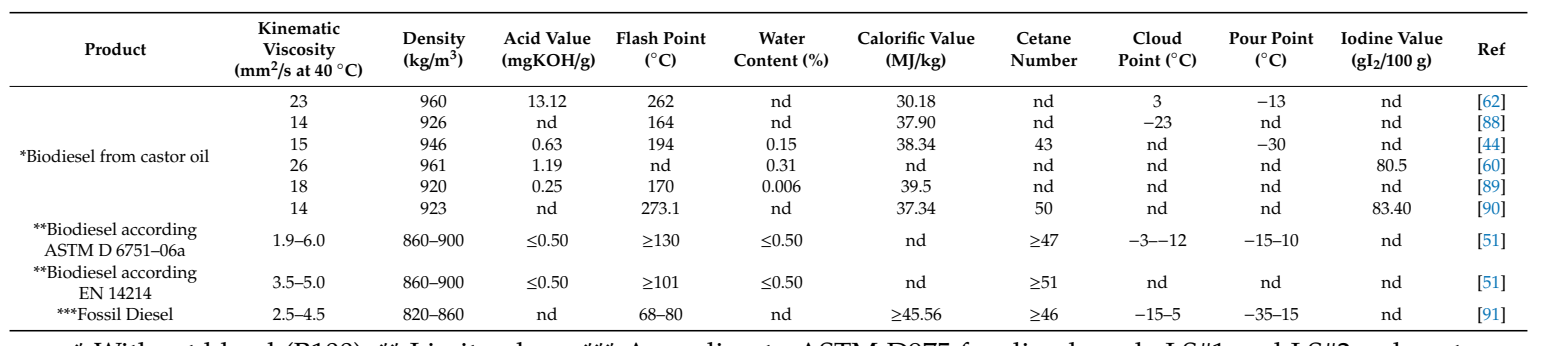

* Without blend (B100); ${ }^{* *}$ Limit values; ${ }^{* * *}$ According to ASTM D975 for diesel grade LS\#1 and LS\#2; nd: not determined; ASTM D 6751-06a: Standard Specification for Biodiesel Fuel Blend Stock (B100) for Middle Distillate Fuels. EN 14214: European Committee for Standardization for biodiesel.

Regarding worldwide biodiesel production using castor oil as a feedstock, so far there is no specific report or inventor. Geographically, the biodiesel production is widely diverse around the world. However, the main vegetable oils for biodiesel production have been reported to be soybean, rapeseed, palm, and cooking oils, and according to Renewables Global Status Report in 2019 until 2018, the world production of biodiesel was 34 billion L (Figure 4), with United States, Brazil, Argentina, Indonesia, and Germany being the five countries with the highest production of this important biofuel. 


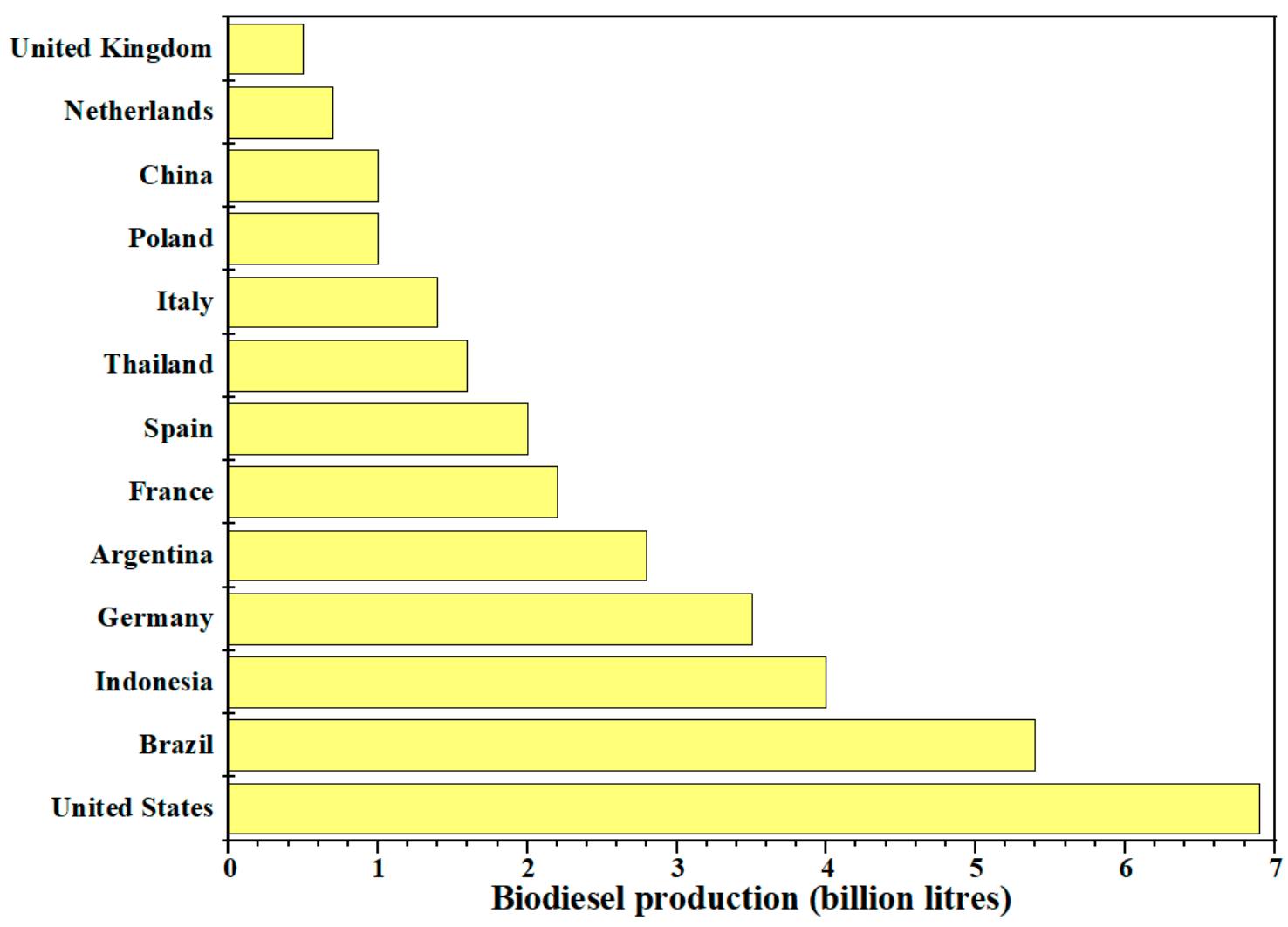

Figure 4. Top countries on biodiesel production.

\section{Biodiesel Up-Grading}

The purity of biodiesel has a strong influence on fuel properties. These impurities are formed when the transesterification reaction is carried out. To remove them, the biodiesel must be separated from glycerol (the main contaminant) before continuing with further refining processes [51]. The separation of glycerol is generally performed by decantation, filtration, or centrifugation, using the insolubility and the difference of densities between biodiesel and glycerol. The separation of glycerol from biodiesel by decanting is economic but very slow. The use of centrifuges and filters is more efficient but requires more complex and expensive operating units [84]. Table 8 shows different substances which are considered impurities in biodiesel and the problems that they can cause in combustion engines.

Table 8. Impurities of biodiesel and their effect on combustion engines.

\begin{tabular}{|c|c|c|}
\hline Impurities & Effect & Ref. \\
\hline Free fatty acids (FFA) & $\begin{array}{c}\text { Corrosion } \\
\text { Low oxidation stability }\end{array}$ & {$[92,93]$} \\
\hline Water & Corrosion & \\
\hline Methanol & $\begin{array}{l}\text { Low values of viscosity and density } \\
\text { Low flashpoint } \\
\text { Corrosion of aluminum and zinc surfaces }\end{array}$ & [93] \\
\hline Glycerides & $\begin{array}{c}\text { High viscosity } \\
\text { Carbon residues in the injection system } \\
\text { Crystallization }\end{array}$ & [94] \\
\hline Metals (soap, catalyst) & $\begin{array}{c}\text { Carbon residues in the injection system } \\
\text { Filter fuel system blockage } \\
\text { Power loss }\end{array}$ & [95] \\
\hline Glycerol & $\begin{array}{l}\text { Problems caused by sediment accumulation } \\
\text { Increased emission of acrolein and aldehydes }\end{array}$ & [61] \\
\hline
\end{tabular}


Due to the peculiar characteristics such as highly viscous, miscible in alcohol and acetic acid, low solidification point, low iodine value, low acid value, and low freezing point of castor oil, after transesterification, the formed products are not separated in two liquid phases. This hinders the separation of glycerol and biodiesel $[60,96]$. Some alternatives to solve this problem are washing the mixture with water immediately after the transesterification, using oil mixtures such as soybean/castor or cotton/castor that induce the formation of two phases (biodiesel-glycerol) and improve the biodiesel purification. Separation of the oil mix can also be performed by the addition of different proportions of glycerol to facilitate the formation and separation of two phases $[10,11]$.

After glycerol removal, the biodiesel is refined and this consists of removing impurity compounds such as monoglycerides, diglycerides, triglycerides, catalysts, soap, or alcohol traces. The remotion or elimination of impurities compounds is essential in biodiesel production to meet standard specifications such as ASTM 6751-06a and EN 14214. For example, the European regulation set that biodiesel must have a purity of at least $96.5 \%$ [61,84]. Generally, alcohol is removed by vacuum distillation or flash evaporation, whereas catalyst and soap triglycerides are removed using washing or adsorption methods. Washing can be performed with distilled water, acids followed by distilled water or organic solvent followed by water. After washing, biodiesel needs to be dried by heating at $105^{\circ} \mathrm{C}[97,98]$. The adsorption of impurities can be performed using diatomaceous earth, zeolite, carbon, activated clay, silica, bleaching earth, ion exchange resins (Amberlite ${ }^{\circledR}$ or Purolite ${ }^{\circledR}$ ), cellulose, sawdust, and powder of magnesium silicate $\left(\right.$ Magnesol ${ }^{\circledR}$ or Trisyl $\left.{ }^{\circledR}\right)[84,99]$.

Washing is an appropriate alternative to obtain good quality biodiesel, but this is not environmentally friendly due to consuming a large amount of water and in the same proportion generating a greater amount of wastewater. Furthermore, after washing, the residual moisture content in the biodiesel contributes during the ester hydrolysis and increases their acidity, which consequently decreases its shelf life. Adsorption of impurities is an alternative to these problems but the process is relatively expensive as additional mixing units are required as well as different types of absorbents that they cannot be reused (potato, corn, cassava, and rice starch, silica gel, bleaching earth, bleached cellulose, or silica-smectite mixture) [92,100]. During oil transesterification, several undesirable by-products are produced, including steryl glycosides, which can precipitate and therefore need to be removed to prevent filter clogging and engine failure [101,102].

Purification in biodiesel production plays a key role to obtain the quality standards established by different energy institutions. However, it is advisable to perform a previous investigation of current purification methods, because some of them can use large amounts of water (wet wash) and hence a large amount of wastewater, making the process unsustainable for biofuel production. Likewise, dry wash processes have generated a growing interest among the scientific community due to their high selectivity in the compounds that they want to eliminate (mainly oxygen). However, the research, optimization, and scale-up of this technology is still in progress.

\section{By-Products of Biodiesel Production}

\subsection{Residual Cake}

The residual cake obtained from oil extraction and transesterification accounts for nearly $50 \%$ of the total seed biomass. These materials are rich in proteins, carbohydrates, and fiber and can be valorized to different products such as fertilizer, cattle feed, and bioethanol [103]. Abada et al. [104] performed a hydrolysis treatment with a Pseudomonas poae $\mathrm{AB} 3$ on the cake from castor oil extraction to produce bioethanol. Likewise, castor cake was used as a nematicide against Meloidogyne incognita by Pedroso et al. [105]. They reported when the castor bean cake is incorporated in soil, a decrease of $95 \%$ the root-nematodes occurs. Finally, one of the most common uses of the residual cake is as feed for goats, lamb, cattle, and chickens [106-108]. 


\subsection{Glycerol}

The biodiesel from vegetable oil contains $10 \%$ of glycerol. It is estimated that in 2020 , about 40,000 tons of glycerol will be produced as a by-product of biodiesel production [57,109-111]. Glycerol is a potential feedstock to produce lipids by fermentation and transform them into biodiesel. This type of process generally involves different species of yeast with the ability to accumulate lipids, especially triglycerides with similar characteristics to those present in vegetable oils. Duarte et al. [112], showed the feasibility of producing lipids using crude glycerol as a substrate by fermentation with a strain of Candida sp. LEB-M3. They suggest that it is possible to produce commercial-grade biodiesel from this kind of cell-oil by controlling the aeration and agitation to produce suitable fatty acid profiles.

Crude glycerol has also been used as a carbon source to produce unicellular protein. For example, Pichia pastoris grows better in crude glycerol than in commercial glycerol presenting cell densities 1.5-2-fold higher for the first one [109]. Crude glycerol derived from palm and canola oil has also been used to produce 1,3-propanediol without affecting the growth ratio of the microorganisms. Under industrial operating conditions, the production rate of 1,3-propanediol using Lactobacillus diolivorans has been reported to be $0.45 \mathrm{~g} / \mathrm{l}-\mathrm{h}$ [110]. Furthermore, crude glycerol has been used to produce fumaric acid with a strain of Rhizopus arrhizus, decreasing the production costs by $14 \%$ in comparison to the use of glucose as a substrate. In some research, it has been observed that crude glycerol may inhibit the growth of some microorganisms, mainly due to the presence of saponified fatty acids $[113,114]$. To avoid inhibition, crude glycerol can be conditioned removing soap by $\mathrm{NaCl}$ and $\mathrm{MgSO}_{4}$ treatment, removing salts by alcohol-precipitation, adsorbing contaminants on activated carbon, adjusting $\mathrm{pH}$, and removing solvents. Subsequently, glycerol can be used to produce other valued products, such as bio-hydrogen using Enterobacter aerogenes, and oil and biomass using Yarrowia lipolytica $[13,111]$.

\section{Conclusions}

Biodiesel production around the world is produced from different feedstocks and specifically vegetable oils. Moreover, a wide variety of methods to obtain this biofuel exist, however, the most common is through transesterification. Biodiesel from castor oil offers environmental and technical benefits, therefore, it can be considered as a viable alternative in the present and future to other forms of biodiesel. R. communis plants have a strong adaptation to different weather, and one of the main characteristics of these plants is being able to grow in marginal soils. This characteristic contributes directly to decrease land use for biofuel production and preserve it to cultivate products used for human consumption. Moreover, non-edible vegetable oil from castor bean seeds is a suitable feedstock to replace $40-50 \%$ of edible oil currently used in biodiesel production. Furthermore, the ricinoleic fatty acid offers advantages to the transesterification process such as high miscibility in alcohol, low reaction temperature, low iodine content, and low freezing point. Biodiesel from castor oil offers a wide range of benefits, among them, is that it is biodegradable, non-toxic, renewable, and safe handling, it can be used alone, and it presents low greenhouse gas emission, high flash point, and similar energetic content to fossil diesel. However, when castor biodiesel is used without blending (B100) some challenges are present, for example, the high viscosity and high density decrease its ignition and can be a potential risk for vehicle engines. Finally, it is necessary to improve the transesterification process to decrease the final price and can be competitive with petrodiesel cost.

Author Contributions: Conceptualization, F.S.-S. and A.A.R.; Formal Analysis, G.S.O.-G. and N.G.-F.; Investigation, G.S.O.-G. and N.G.-F.; Writing-Original Draft Preparation, G.S.O.-G. and N.G.-F.; Writing-Review \& Editing, F.S.-S., R.S. S.K.B. and A.A.R; Supervision, F.S.-S. and A.A.R. All authors have read and agreed to the published version of the manuscript.

Acknowledgments: The authors thank Instituto Tecnologico Superior de Perote (Mexico) and Institute National de la Recherche Scientifique-Eau Terre Environnement, and James and Joanne Love Chair in Environmental Engineering at York University for the support provided.

Conflicts of Interest: The authors declare no conflict of interest. 


\section{References}

1. Chen, S.-Y.; Lao-ubol, S.; Mochizuki, T.; Abe, Y.; Toba, M.; Yoshimura, Y. Production of Jatropha biodiesel fuel over sulfonic acid-based solid acids. Bioresour. Technol. 2014, 157, 346-350. [CrossRef] [PubMed]

2. Keera, S.T.; Sabagh, S.M.E.; Taman, A.R. Castor oil biodiesel production and optimization. Egypt. J. Pet. 2018, 27, 979-984. [CrossRef]

3. Panagiotopoulos, I.A.; Pasias, S.; Bakker, R.R.; de Vrije, T.; Papayannakos, N.; Claassen, P.A.M.; Koukios, E.G. Biodiesel and biohydrogen production from cotton-seed cake in a biorefinery concept. Bioresour. Technol. 2013, 136, 78-86. [CrossRef] [PubMed]

4. Adesanya, V.O.; Cadena, E.; Scott, S.A.; Smith, A.G. Life cycle assessment on microalgal biodiesel production using a hybrid cultivation system. Bioresour. Technol. 2014, 163, 343-355. [CrossRef]

5. Acharya, N.; Nanda, P.; Panda, S.; Acharya, S. A comparative study of stability characteristics of mahua and jatropha biodiesel and their blends. J. King Saud Univ. - Eng. Sci. 2019, 31, 184-190. [CrossRef]

6. Kayode, B.; Hart, A. An overview of transesterification methods for producing biodiesel from waste vegetable oils. Biofuels 2019, 10, 419-437. [CrossRef]

7. Callegari, A.; Bolognesi, S.; Cecconet, D.; Capodaglio, A.G. Production technologies, current role, and future prospects of biofuels feedstocks: A state-of-the-art review. Crit. Rev. Environ. Sci. Technol. 2020, 50, $384-436$. [CrossRef]

8. Bauddh, K.; Singh, K.; Singh, B.; Singh, R.P. Ricinus communis: A robust plant for bio-energy and phytoremediation of toxic metals from contaminated soil. Ecol. Eng. 2015, 84, 640-652. [CrossRef]

9. McKeon, T.A. Castor (Ricinus communis L.). In Industrial Oil Crops; Elsevier: Amsterdam, The Netherlands, 2016; pp. 75-112. ISBN 978-1-893997-98-1.

10. Yan, J.; Zheng, X.; Du, L.; Li, S. Integrated lipase production and in situ biodiesel synthesis in a recombinant Pichia pastoris yeast: An efficient dual biocatalytic system composed of cell free enzymes and whole cell catalysts. Biotechnol. Biofuels 2014, 7, 55. [CrossRef]

11. Ramachandran, K.; Sivakumar, P.; Suganya, T.; Renganathan, S. Production of biodiesel from mixed waste vegetable oil using an aluminium hydrogen sulphate as a heterogeneous acid catalyst. Bioresour. Technol. 2011, 102, 7289-7293. [CrossRef]

12. Issariyakul, T.; Dalai, A.K. Biodiesel from vegetable oils. Renew. Sustain. Energy Rev. 2014, 31, 446-471. [CrossRef]

13. Poli, J.S.; da Silva, M.A.N.; Siqueira, E.P.; Pasa, V.M.D.; Rosa, C.A.; Valente, P. Microbial lipid produced by Yarrowia lipolytica QU21 using industrial waste: A potential feedstock for biodiesel production. Bioresour. Technol. 2014, 161, 320-326. [CrossRef] [PubMed]

14. Aranda-Rickert, A.; Morzán, L.; Fracchia, S. Seed oil content and fatty acid profiles of five Euphorbiaceae species from arid regions in Argentina with potential as biodiesel source. Seed Sci. Res. 2011, 21, 63-68. [CrossRef]

15. Datta, A.; Mandal, B.K. Use of Jatropha Biodiesel as a Future Sustainable Fuel. Energy Technol. Policy 2014, 1, 8-14. [CrossRef]

16. Sanghamitra, K.; Oramas, R.V.; Prasad, R.N. Comparative Yeild and Oil Quality of Toxic and Non-Toxic Mexican Jatropha curcas Grown in the Same Agroclimatic Conditions. Am. J. Plant Sci. 2014, 05, $230-234$. [CrossRef]

17. Sagiroglu, A.; Ozcan, H.M.; Isbilir, S.S.; Paluzar, H.; Toprakkiran, N.M. Alkali Catalysis of Different Vegetable Oils for Comparisons of Their Biodiesel Productivity. J. Sustain. Bioenergy Syst. 2013, 3, 79-85. [CrossRef]

18. Pinzi, S.; Leiva, D.; López-García, I.; Redel-Macías, M.D.; Dorado, M.P. Latest trends in feedstocks for biodiesel production. Biofuels Bioprod. Biorefining 2014, 8, 126-143. [CrossRef]

19. Raiol, L.C.B.; Kuss, F.; Silva, A.G.M.; Soares, B.C.; de Souza, K.D.S.; Colodo, J.C.N.; de Brito Lourenço Júnior, J.; de Ávila, S.C. Nutrient intake and digestibility of the lipid residue of biodiesel from palm oil in sheep. Rev. Bras. Zootec. 2012, 41, 2364-2368. [CrossRef]

20. Li, M.; Zheng, Y.; Chen, Y.; Zhu, X. Biodiesel production from waste cooking oil using a heterogeneous catalyst from pyrolyzed rice husk. Bioresour. Technol. 2014, 154, 345-348. [CrossRef]

21. Buy Organic \& Kosher Castor Oil - Drums, Pails, \& Bags | 18c. Available online: https://www.ah18c.com/enus/castor-oil/castor-oil-castor\%20oil?returnurl=\%2fen-us\%2fcastor-oil\%2f (accessed on 27 April 2020). 
22. Jatropha Oil Crude Jatropha Oil/crude Jatropha Oil Subsidize Prices In Sa - Buy Canola Oil Biodiesel, Jatropha Curcas Oil, Crude Coconut Oil Product on Alibaba.com. Available online: https://www.alibaba.com/product-detail/JatrophaOil-Crude-Jatropha-Oil-Crude_62015801964.html?spm=a2700.7724857.normalList.27.182b26c93tbdv0\&bypass=true (accessed on 27 April 2020).

23. International Prices of Oilseeds and Oilmeals Unchanged, Those of Vegetable Oils Appreciate Further | Food Price Monitoring and Analysis (FPMA) | Food and Agriculture Organization of the United Nations. Available online: http://www.fao.org/giews/food-prices/international-prices/detail/en/c/1181877/ (accessed on 20 April 2020).

24. Used cooking oil (uco) -International Market Price- B2B- Import Export- Manufacturers, Wholesalers- Sell Leads, Offers- Free B2B Website- Free B2B Directory- Free Listing- Suppliers, Exporters.2139. Available online: http://www.importexportplatform.com/2139_used_cooking_oil_(uco)_sellers.html (accessed on 27 April 2020).

25. Aguirre, A.; Peiru, S.; Eberhardt, F.; Vetcher, L.; Cabrera, R.; Menzella, H.G. Enzymatic hydrolysis of steryl glucosides, major contaminants of vegetable oil-derived biodiesel. Appl. Microbiol. Biotechnol. 2014, 98, 4033-4040. [CrossRef]

26. Hincapié, G.; Moreno, A.; López, D. Transesterificación de aceite de higuerilla crudo utilizando catalizadores heterogéneos-estudio preliminar. Dyna 2011, 78, 176-181.

27. Mutlu, H.; Meier, M.A.R. Castor oil as a renewable resource for the chemical industry. Eur. J. Lipid Sci. Technol. 2010, 112, 10-30. [CrossRef]

28. Rajkumari, K.; Rokhum, L. A sustainable protocol for production of biodiesel by transesterification of soybean oil using banana trunk ash as a heterogeneous catalyst. Biomass Convers. Biorefinery 2020. [CrossRef]

29. Rial, R.C.; de Freitas, O.N.; Nazário, C.E.D.; Viana, L.H. Biodiesel from soybean oil using Porcine pancreas lipase immobilized on a new support: P-nitrobenzyl cellulose xanthate. Renew. Energy 2020, 149, $970-979$. [CrossRef]

30. Avramović, J.M.; Stamenković, O.S.; Todorović, Z.B.; Lazić, M.L.; Veljković, V.B. The optimization of the ultrasound-assisted base-catalyzed sunflower oil methanolysis by a full factorial design. Fuel Process. Technol. 2010, 91, 1551-1557. [CrossRef]

31. Da Rós, P.C.M.; Freitas, L.; Perez, V.H.; de Castro, H.F. Enzymatic synthesis of biodiesel from palm oil assisted by microwave irradiation. Bioprocess Biosyst. Eng. 2013, 36, 443-451. [CrossRef] [PubMed]

32. Batista, A.C.F.; Vieira, A.T.; Rodrigues, H.S.; Silva, T.A.; Assunção, R.M.N.; Beluomini, M.A.; Rezende, H.P.; Hernandez-Terrones, M.G. Production and physicochemical characterization of methylic and ethylic biodiesel from canola oil/obtenção e caracterização do biodiesel de canola pelas rotas metílica e etílica. Rev. Bras. Eng. Biossistemas 2014, 8, 289. [CrossRef]

33. Mata, T.M.; Martins, A.A.; Sikdar, S.K.; Costa, C.A.V. Sustainability considerations of biodiesel based on supply chain analysis. Clean Technol. Environ. Policy 2011, 13, 655-671. [CrossRef]

34. Ali, M.; Watson, I.A. Comparison of oil extraction methods, energy analysis and biodiesel production from flax seeds: Microwave, ultrasonic and solvent extraction methods for flax seeds. Int. J. Energy Res. 2014, 38, 614-625. [CrossRef]

35. Fore, S.R.; Porter, P.; Lazarus, W. Net energy balance of small-scale on-farm biodiesel production from canola and soybean. Biomass Bioenergy 2011, 35, 2234-2244. [CrossRef]

36. Parawira, W. Biodiesel production from Jatropha curcas: A review. Sci. Res. Essays 2010, 5, 1796-1808.

37. Jokić, S.; Nagy, B.; Zeković, Z.; Vidović, S.; Bilić, M.; Velić, D.; Simándi, B. Effects of supercritical $\mathrm{CO}_{2}$ extraction parameters on soybean oil yield. Food Bioprod. Process. 2012, 90, 693-699. [CrossRef]

38. Sangaletti-Gerhard, N.; Romanelli, T.L.; de Souza Vieira, T.M.F.; Navia, R.; Regitano-d'Arce, M.A.B. Energy flow in the soybean biodiesel production chain using ethanol as solvent extraction of oil from soybeans. Biomass Bioenergy 2014, 66, 39-48. [CrossRef]

39. Sawada, M.M.; Venâncio, L.L.; Toda, T.A.; Rodrigues, C.E.C. Effects of different alcoholic extraction conditions on soybean oil yield, fatty acid composition and protein solubility of defatted meal. Food Res. Int. 2014, 62, 662-670. [CrossRef]

40. Danlami, J.M.; Arsad, A.; Zaini, M.A.A. Characterization and process optimization of castor oil (Ricinus communis L.) extracted by the soxhlet method using polar and non-polar solvents. J. Taiwan Inst. Chem. Eng. 2015, 47, 99-104. [CrossRef] 
41. del Valle, J.M.; Núñez, G.A.; Aravena, R.I. Supercritical $\mathrm{CO}_{2}$ oilseed extraction in multi-vessel plants. 1. Minimization of operational cost. J. Supercrit. Fluids 2014, 92, 197-207. [CrossRef]

42. Núñez, G.A.; del Valle, J.M. Supercritical $\mathrm{CO}_{2}$ oilseed extraction in multi-vessel plants. 2. Effect of number and geometry of extractors on production cost. J. Supercrit. Fluids 2014, 92, 324-334. [CrossRef]

43. Kanitkar, A.; Sabliov, C.M.; Balasubramanian, S.; Lima, M.; Boldor, D. Microwave-Assisted Extraction of Soybean and Rice Bran Oil: Yield and Extraction Kinetics. Trans. ASABE 2011, 54, 1387-1394. [CrossRef]

44. Elango, R.K.; Sathiasivan, K.; Muthukumaran, C.; Thangavelu, V.; Rajesh, M.; Tamilarasan, K. Transesterification of castor oil for biodiesel production: Process optimization and characterization. Microchem. J. 2019, 145, 1162-1168. [CrossRef]

45. Meneghetti, S.M.P.; Meneghetti, M.R.; Wolf, C.R.; Silva, E.C.; Lima, G.E.S.; de Lira Silva, L.; Serra, T.M.; Cauduro, F.; de Oliveira, L.G. Biodiesel from Castor Oil: A Comparison of Ethanolysis versus Methanolysis. Energy Fuels 2006, 20, 2262-2265. [CrossRef]

46. Cavalcante, K.S.B.; Penha, M.N.C.; Mendonça, K.K.M.; Louzeiro, H.C.; Vasconcelos, A.C.S.; Maciel, A.P.; de Souza, A.G.; Silva, F.C. Optimization of transesterification of castor oil with ethanol using a central composite rotatable design (CCRD). Fuel 2010, 89, 1172-1176. [CrossRef]

47. Eze, V.C.; Phan, A.N.; Harvey, A.P. A more robust model of the biodiesel reaction, allowing identification of process conditions for significantly enhanced rate and water tolerance. Bioresour. Technol. 2014, 156, $222-231$. [CrossRef]

48. Aransiola, E.F.; Ojumu, T.V.; Oyekola, O.O.; Madzimbamuto, T.F.; Ikhu-Omoregbe, D.I.O. A review of current technology for biodiesel production: State of the art. Biomass Bioenergy 2014, 61, 276-297. [CrossRef]

49. Cancela, A.; Maceiras, R.; Urrejola, S.; Sanchez, A. Microwave-Assisted Transesterification of Macroalgae. Energies 2012, 5, 862-871. [CrossRef]

50. Dias, J.M.; Araújo, J.M.; Costa, J.F.; Alvim-Ferraz, M.C.M.; Almeida, M.F. Biodiesel production from raw castor oil. Energy 2013, 53, 58-66. [CrossRef]

51. Bateni, H.; Saraeian, A.; Able, C.; Karimi, K. Biodiesel Purification and Upgrading Technologies. In Biodiesel; Tabatabaei, M., Aghbashlo, M., Eds.; Springer International Publishing: Cham, Switzerland, 2019; Volume 8, pp. 57-100. ISBN 978-3-030-00984-7.

52. Devi, B.L.A.P.; Reddy, T.V.K.; Lakshmi, K.V.; Prasad, R.B.N. A green recyclable SO3H-carbon catalyst derived from glycerol for the production of biodiesel from FFA-containing karanja (Pongamia glabra) oil in a single step. Bioresour. Technol. 2014, 153, 370-373. [CrossRef] [PubMed]

53. Sun, C.; Qiu, F.; Yang, D.; Ye, B. Preparation of biodiesel from soybean oil catalyzed by Al-Ca hydrotalcite loaded with K2CO3 as heterogeneous solid base catalyst. Fuel Process. Technol. 2014, 126, 383-391. [CrossRef]

54. Badday, A.S.; Abdullah, A.Z.; Lee, K.-T. Transesterification of crude Jatropha oil by activated carbon-supported heteropolyacid catalyst in an ultrasound-assisted reactor system. Renew. Energy 2014, 62, 10-17. [CrossRef]

55. Du, L.; Ding, S.; Li, Z.; Lv, E.; Lu, J.; Ding, J. Transesterification of castor oil to biodiesel using NaY zeolite-supported La2O3 catalysts. Energy Convers. Manag. 2018, 173, 728-734. [CrossRef]

56. Baskar, G.; Selvakumari, I.A.E.; Aiswarya, R. Biodiesel production from castor oil using heterogeneous Ni doped ZnO nanocatalyst. Bioresour. Technol. 2018, 250, 793-798. [CrossRef]

57. Kai, T.; Mak, G.L.; Wada, S.; Nakazato, T.; Takanashi, H.; Uemura, Y. Production of biodiesel fuel from canola oil with dimethyl carbonate using an active sodium methoxide catalyst prepared by crystallization. Bioresour. Technol. 2014, 163, 360-363. [CrossRef] [PubMed]

58. Ganesan, D.; Rajendran, A.; Thangavelu, V. An overview on the recent advances in the transesterification of vegetable oils for biodiesel production using chemical and biocatalysts. Rev. Environ. Sci. Biotechnol. 2009, 8 , 367-394. [CrossRef]

59. Aboelazayem, O.; El-Gendy, N.S.; Abdel-Rehim, A.A.; Ashour, F.; Sadek, M.A. Biodiesel production from castor oil in Egypt: Process optimisation, kinetic study, diesel engine performance and exhaust emissions analysis. Energy 2018, 157, 843-852. [CrossRef]

60. Sánchez, N.; Encinar, J.R.; Nogales, S.; González, J. Biodiesel Production from Castor Oil by Two-Step Catalytic Transesterification: Optimization of the Process and Economic Assessment. Catalysts 2019, 9, 864. [CrossRef]

61. Zeng, D.; Li, R.; Feng, M.; Fang, T. Continuous Esterification of Free Fatty Acids in Crude Biodiesel by an Integrated Process of Supercritical Methanol and Sodium Methoxide Catalyst. Appl. Biochem. Biotechnol. 2014, 174, 1484-1495. [CrossRef] 
62. Kumar, D.; Das, T.; Giri, B.S.; Verma, B. Preparation and characterization of novel hybrid bio-support material immobilized from Pseudomonas cepacia lipase and its application to enhance biodiesel production. Renew. Energy 2020, 147, 11-24. [CrossRef]

63. Andrade, T.A.; Martín, M.; Errico, M.; Christensen, K.V. Biodiesel production catalyzed by liquid and immobilized enzymes: Optimization and economic analysis. Chem. Eng. Res. Des. 2019, 141, 1-14. [CrossRef]

64. Amini, Z.; Ilham, Z.; Ong, H.C.; Mazaheri, H.; Chen, W.-H. State of the art and prospective of lipase-catalyzed transesterification reaction for biodiesel production. Energy Convers. Manag. 2017, 141, 339-353. [CrossRef]

65. Jiang, Y.; Liu, X.; Chen, Y.; Zhou, L.; He, Y.; Ma, L.; Gao, J. Pickering emulsion stabilized by lipase-containing periodic mesoporous organosilica particles: A robust biocatalyst system for biodiesel production. Bioresour. Technol. 2014, 153, 278-283. [CrossRef]

66. Lam, M.K.; Lee, K.T.; Mohamed, A.R. Homogeneous, heterogeneous and enzymatic catalysis for transesterification of high free fatty acid oil (waste cooking oil) to biodiesel: A review. Biotechnol. Adv. 2010, 28, 500-518. [CrossRef]

67. Suganya, T.; Kasirajan, R.; Renganathan, S. Ultrasound-enhanced rapid in situ transesterification of marine macroalgae Enteromorpha compressa for biodiesel production. Bioresour. Technol. 2014, 156, 283-290. [CrossRef] [PubMed]

68. Elizabeth Grant, G.; Gnaneswar Gude, V. Kinetics of ultrasonic transesterification of waste cooking oil. Environ. Prog. Sustain. Energy 2014, 33, 1051-1058. [CrossRef]

69. Sabzimaleki, M.; Ghobadian, B.; Farsibaf, M.M.; Najafi, G.; Soufi, M.D.; Ardebili, S.M.S. Optimization of Biodiesel Ultrasound-Assisted Synthesis from Castor Oil Using Response Surface Methodology (RSM). Chem. Prod. Process Model. 2015, 10, 123-133. [CrossRef]

70. Zhang, X.; Yan, S.; Tyagi, R.D.; Surampalli, R.Y.; Valéro, J.R. Ultrasonication aided in-situ transesterification of microbial lipids to biodiesel. Bioresour. Technol. 2014, 169, 175-180. [CrossRef] [PubMed]

71. Shuit, S.H.; Ong, Y.T.; Lee, K.T.; Subhash, B.; Tan, S.H. Membrane technology as a promising alternative in biodiesel production: A review. Biotechnol. Adv. 2012, 30, 1364-1380. [CrossRef]

72. Kumar, R.; Ghosh, A.K.; Pal, P. Sustainable Production of Biofuels through Membrane-Integrated Systems. Sep. Purif. Rev. 2019, 1-22. [CrossRef]

73. Zahan, K.A.; Kano, M. Technological Progress in Biodiesel Production: An Overview on Different Types of Reactors. Energy Procedia 2019, 156, 452-457. [CrossRef]

74. Xu, W.; Gao, L.; Wang, S.; Xiao, G. Biodiesel production in a membrane reactor using MCM-41 supported solid acid catalyst. Bioresour. Technol. 2014, 159, 286-291. [CrossRef]

75. Gude, V.; Patil, P.; Martinez-Guerra, E.; Deng, S.; Nirmalakhandan, N. Microwave energy potential for biodiesel production. Sustain. Chem. Process. 2013, 1, 5. [CrossRef]

76. Nayak, S.N.; Bhasin, C.P.; Nayak, M.G. A review on microwave-assisted transesterification processes using various catalytic and non-catalytic systems. Renew. Energy 2019, 143, 1366-1387. [CrossRef]

77. Thakkar, K.; Shah, K.; Kodgire, P.; Kachhwaha, S.S. In-situ reactive extraction of castor seeds for biodiesel production using the coordinated ultrasound - microwave irradiation: Process optimization and kinetic modeling. Ultrason. Sonochem. 2019, 50, 6-14. [CrossRef] [PubMed]

78. Patil, P.; Gude, V.G.; Pinappu, S.; Deng, S. Transesterification kinetics of Camelina sativa oil on metal oxide catalysts under conventional and microwave heating conditions. Chem. Eng. J. 2011, 168, 1296-1300. [CrossRef]

79. Mazubert, A.; Taylor, C.; Aubin, J.; Poux, M. Key role of temperature monitoring in interpretation of microwave effect on transesterification and esterification reactions for biodiesel production. Bioresour. Technol. 2014, 161, 270-279. [CrossRef] [PubMed]

80. Zhang, A.; Wang, Q.; He, Y.; Lai, P.; Miu, Y.; Xiao, Z. Preparation of Biodiesel Based on Alkaline Ionic Liquid [Bmim]OH Catalyzed Castor Oil. IOP Conf. Ser. Mater. Sci. Eng. 2020, 729, 012048. [CrossRef]

81. Molefe, M.; Nkazi, D.; Mukaya, H.E. Method Selection for Biojet and Biogasoline Fuel Production from Castor Oil: A Review. Energy Fuels 2019, 33, 5918-5932. [CrossRef]

82. Kaur, R.; Bhaskar, T. Chapter 11-Potential of castor plant (Ricinus communis) for production of biofuels, chemicals, and value-added products. In Waste Biorefinery; Bhaskar, T., Pandey, A., Rene, E.R., Tsang, D.C.W., Eds.; Elsevier: Amsterdam, The Netherlands, 2020; pp. 269-310. ISBN 978-0-12-818228-4.

83. Schmutzler, L.O.F. (54) PROCESS FOR REFINING GLYCERIDE OIL. 4. Available online: https://patents. google.com/patent/US5248799A/en (accessed on 27 February 2020). 
84. Atadashi, I.M.; Aroua, M.K.; Aziz, A.R.A.; Sulaiman, N.M.N. Membrane biodiesel production and refining technology: A critical review. Renew. Sustain. Energy Rev. 2011, 15, 5051-5062. [CrossRef]

85. Shrirame, H.Y.; Panwar, N.L.; Bamniya, B.R. Bio Diesel from Castor Oil-A Green Energy Option. Low Carbon Econ. 2011, 2, 1-6. [CrossRef]

86. Tesfa, B.; Mishra, R.; Gu, F.; Powles, N. Prediction models for density and viscosity of biodiesel and their effects on fuel supply system in CI engines. Renew. Energy 2010, 35, 2752-2760. [CrossRef]

87. Dwivedi, G.; Sharma, M.P. Impact of cold flow properties of biodiesel on engine performance. Renew. Sustain. Energy Rev. 2014, 31, 650-656. [CrossRef]

88. Hajlari, S.A.; Najafi, B.; Ardabili, S.F. Castor oil, a source for biodiesel production and its impact on the diesel engine performance. Renew. Energy Focus 2019, 28, 1-10. [CrossRef]

89. Banerjee, A.; Varshney, D.; Kumar, S.; Chaudhary, P.; Gupta, V.K. Biodiesel production from castor oil: ANN modeling and kinetic parameter estimation. Int. J. Ind. Chem. 2017, 8, 253-262. [CrossRef]

90. Bueno, A.V.; Pereira, M.P.B.; de Oliveira Pontes, J.V.; de Luna, F.M.T.; Cavalcante, C.L. Performance and emissions characteristics of castor oil biodiesel fuel blends. Appl. Therm. Eng. 2017, 125, 559-566. [CrossRef]

91. Atabani, A.E.; Silitonga, A.S.; Ong, H.C.; Mahlia, T.M.I.; Masjuki, H.H.; Badruddin, I.A.; Fayaz, H. Non-edible vegetable oils: A critical evaluation of oil extraction, fatty acid compositions, biodiesel production, characteristics, engine performance and emissions production. Renew. Sustain. Energy Rev. 2013, 18, 211-245. [CrossRef]

92. Gomes, M.G.; Santos, D.Q.; de Morais, L.C.; Pasquini, D. Purification of biodiesel by dry washing, employing starch and cellulose as natural adsorbents. Fuel 2015, 155, 1-6. [CrossRef]

93. Fan, X.; Burton, R.; Austic, G. Preparation and characterization of biodiesel produced from fish oil. Chem. Technol. Fuels Oils 2010, 46, 287-293. [CrossRef]

94. Tyagi, O.S.; Atray, N.; Kumar, B.; Datta, A. Production, characterization and development of standards for biodiesel-A review. MAPAN 2010, 25, 197-218. [CrossRef]

95. Çetinkaya, M.; Karaosmanoğlu, F. Optimization of Base-Catalyzed Transesterification Reaction of Used Cooking Oil. Energy Fuels 2004, 18, 1888-1895. [CrossRef]

96. Maceiras, R.; Rivero, J.J.; Cancela, M.A.; Urrejola, S.; Sanchez, A. Development and modeling of production of biodiesel from sunflower oil. Chem. Technol. Fuels Oils 2010, 46, 154-159. [CrossRef]

97. Berrios, M.; Skelton, R.L. Comparison of purification methods for biodiesel. Chem. Eng. J. 2008, 144, 459-465. [CrossRef]

98. Vasconcelos, A.F.F.; Dantas, M.B.; Filho, M.G.R.; Rosenhaim, R.; Cavalcanti, E.H.S.; Filho, N.R.A.; Sinfrônio, F.S.M.; Santos, I.M.G.; Souza, A.G. Influence of drying processes on oxidative stability of ethyl corn biodiesel by differential scanning calorimetry. J. Therm. Anal. Calorim. 2009, 97, 657-660. [CrossRef]

99. Predojević, Z.J. The production of biodiesel from waste frying oils: A comparison of different purification steps. Fuel 2008, 87, 3522-3528. [CrossRef]

100. Stojkovič, G.; Plazl, I.; Žnidaršič-Plazl, P. 1-Malic acid production within a microreactor with surface immobilised fumarase. Microfluid. Nanofluidics 2011, 10, 627-635. [CrossRef]

101. He, W.; Fang, Z.; Ji, D.; Zhang, K.; Guo, K. Optimization of biodiesel production by continuous microflow system with online separation. Monatshefte Für Chem. Chem. Mon. 2014, 145, 223-227. [CrossRef]

102. Chatzifragkou, A.; Papanikolaou, S.; Kopsahelis, N.; Kachrimanidou, V.; Dorado, M.P.; Koutinas, A.A. Biorefinery development through utilization of biodiesel industry by-products as sole fermentation feedstock for 1,3-propanediol production. Bioresour. Technol. 2014, 159, 167-175. [CrossRef]

103. Chambi, H.N.M.; Lacerda, R.S.; Makishi, G.L.A.; Bittante, A.M.Q.B.; Gomide, C.A.; Sobral, P.J.A. Protein extracted from castor bean (Ricinus communis L.) cake in high $\mathrm{pH}$ results in films with improved physical properties. Ind. Crops Prod. 2014, 61, 217-224. [CrossRef]

104. Abada, E.; Al-Fifi, Z.; Osman, M. Bioethanol production with carboxymethylcellulase of Pseudomonas poae using castor bean (Ricinus communis L.) cake. Saudi J. Biol. Sci. 2019, 26, 866-871. [CrossRef]

105. Pedroso, L.A.; Campos, V.P.; Pedroso, M.P.; Barros, A.F.; Freire, E.S.; Resende, F.M. Volatile organic compounds produced by castor bean cake incorporated into the soil exhibit toxic activity against Meloidogyne incognita. Pest Manag. Sci. 2019, 75, 476-483. [CrossRef]

106. Nicory, I.M.C.; de Carvalho, G.G.P.; Ribeiro, O.L.; Santos, S.A.; da Silva, F.F.; Silva, R.R.; Costa Lopes, L.S.; Souza, F.N.C.; de Freitas, J.E., Jr. Productive and metabolic parameters in lambs fed diets with castor seed meal. Livest. Sci. 2015, 181, 171-178. [CrossRef] 
107. Akande, T.O.; Odunsi, A.A.; Akinfala, E.O. A review of nutritional and toxicological implications of castor bean ( R. communis L.) meal in animal feeding systems. J. Anim. Physiol. Anim. Nutr. 2016, 100, 201-210. [CrossRef]

108. Araújo, R.A.D.; Neiva, J.N.M.; Rogério, M.C.P.; Pimentel, P.G.; Furtado, R.N.; Mariz, L.D.S.; Cândido, M.J.D.; Pompeu, R.C.F.F. Ingestive behavior and physiological parameters of lactating goats fed diets containing detoxified castor cake. Biol. Rhythm Res. 2019, 1-11. [CrossRef]

109. Anastácio, G.S.; Santos, K.O.; Suarez, P.A.Z.; Torres, F.A.G.; De Marco, J.L.; Parachin, N.S. Utilization of glycerin byproduct derived from soybean oil biodiesel as a carbon source for heterologous protein production in Pichia pastoris. Bioresour. Technol. 2014, 152, 505-510. [CrossRef]

110. Pflügl, S.; Marx, H.; Mattanovich, D.; Sauer, M. Heading for an economic industrial upgrading of crude glycerol from biodiesel production to 1,3-propanediol by Lactobacillus diolivorans. Bioresour. Technol. 2014, 152, 499-504. [CrossRef]

111. Sarma, S.J.; Brar, S.K.; Le Bihan, Y.; Buelna, G.; Soccol, C.R. Mitigation of the inhibitory effect of soap by magnesium salt treatment of crude glycerol-A novel approach for enhanced biohydrogen production from the biodiesel industry waste. Bioresour. Technol. 2014, 151, 49-53. [CrossRef]

112. Duarte, S.H.; Ansolin, M.; Maugeri, F. Cultivation of Candida sp. LEB-M3 in glycerol: Lipid accumulation and prediction of biodiesel quality parameters. Bioresour. Technol. 2014, 161, 416-422. [CrossRef]

113. Pott, R.W.M.; Howe, C.J.; Dennis, J.S. The purification of crude glycerol derived from biodiesel manufacture and its use as a substrate by Rhodopseudomonas palustris to produce hydrogen. Bioresour. Technol. 2014, 152, 464-470. [CrossRef]

114. Zhou, Y.; Nie, K.; Zhang, X.; Liu, S.; Wang, M.; Deng, L.; Wang, F.; Tan, T. Production of fumaric acid from biodiesel-derived crude glycerol by Rhizopus arrhizus. Bioresour. Technol. 2014, 163, 48-53. [CrossRef]

(C) 2020 by the authors. Licensee MDPI, Basel, Switzerland. This article is an open access article distributed under the terms and conditions of the Creative Commons Attribution (CC BY) license (http://creativecommons.org/licenses/by/4.0/). 